\title{
Modeling chemistry in and above snow at Summit, Greenland - Part 2: Impact of snowpack chemistry on the oxidation capacity of the boundary layer
}

\author{
J. L. Thomas ${ }^{1,2}$, J. E. Dibb ${ }^{3}$, L. G. Huey ${ }^{4}$, J. Liao ${ }^{4}$, D. Tanner ${ }^{4}$, B. Lefer ${ }^{5}$, R. von Glasow ${ }^{6}$, and J. Stutz ${ }^{2}$ \\ ${ }^{1}$ UPMC Univ. Paris 06, UMR8190, CNRS/INSU - Université Versailles St.-Quentin, LATMOS-IPSL, Paris, France \\ ${ }^{2}$ University of California, Los Angeles; Department of Atmospheric and Oceanic Sciences, Los Angeles, CA 90095, USA \\ ${ }^{3}$ Institute for the Study of Earth, Oceans, and Space, University of New Hampshire, Durham, NH 03824, USA \\ ${ }^{4}$ School of Earth and Atmospheric Sciences, Georgia Institute of Technology, Atlanta, GA 30033, USA \\ ${ }^{5}$ Department of Geosciences, University of Houston, Houston TX 77204, USA \\ ${ }^{6}$ School of Environmental Sciences, University of East Anglia, Norwich, NR4 7TJ, UK
}

Correspondence to: J. L. Thomas (jennie.thomas@latmos.ipsl.fr)

Received: 14 January 2012 - Published in Atmos. Chem. Phys. Discuss.: 21 February 2012

Revised: 21 June 2012 - Accepted: 22 June 2012 - Published: 25 July 2012

\begin{abstract}
The chemical composition of the boundary layer in snow covered regions is impacted by chemistry in the snowpack via uptake, processing, and emission of atmospheric trace gases. We use the coupled one-dimensional (1-D) snow chemistry and atmospheric boundary layer model MISTRA-SNOW to study the impact of snowpack chemistry on the oxidation capacity of the boundary layer. The model includes gas phase photochemistry and chemical reactions both in the interstitial air and the atmosphere. While it is acknowledged that the chemistry occurring at ice surfaces may consist of a true quasi-liquid layer and/or a concentrated brine layer, lack of additional knowledge requires that this chemistry be modeled as primarily aqueous chemistry occurring in a liquid-like layer (LLL) on snow grains. The model has been recently compared with $\mathrm{BrO}$ and $\mathrm{NO}$ data taken on 10 June-13 June 2008 as part of the Greenland Summit Halogen- $\mathrm{HO}_{\mathrm{x}}$ experiment (GSHOX). In the present study, we use the same focus period to investigate the influence of snowpack derived chemistry on $\mathrm{OH}$ and $\mathrm{HO}_{\mathrm{x}}+\mathrm{RO}_{2}$ in the boundary layer. We compare model results with chemical ionization mass spectrometry (CIMS) measurements of the hydroxyl radical $(\mathrm{OH})$ and of the hydroperoxyl radical $\left(\mathrm{HO}_{2}\right)$ plus the sum of all organic peroxy radicals $\left(\mathrm{RO}_{2}\right)$ taken at Summit during summer 2008. Using sensitivity runs we show that snowpack influenced nitrogen cycling and bromine chemistry both increase the oxidation capacity of
\end{abstract}

the boundary layer and that together they increase the midday $\mathrm{OH}$ concentrations. Bromine chemistry increases the $\mathrm{OH}$ concentration by $10-18 \%$ (10\% at noon LT), while snow sourced $\mathrm{NO}_{\mathrm{x}}$ increases $\mathrm{OH}$ concentrations by $20-50 \%$ (27\% at noon LT). We show for the first time, using a coupled onedimensional snowpack-boundary layer model, that air-snow interactions impact the oxidation capacity of the boundary layer and that it is not possible to match measured $\mathrm{OH}$ levels without snowpack $\mathrm{NO}_{\mathrm{x}}$ and halogen emissions. Model predicted HONO compared with mistchamber measurements suggests there may be an unknown HONO source at Summit. Other model predicted $\mathrm{HO}_{\mathrm{x}}$ precursors, $\mathrm{H}_{2} \mathrm{O}_{2}$ and $\mathrm{HCHO}$, compare well with measurements taken in summer 2000, which had lower levels than other years. Over 3 days, snow sourced $\mathrm{NO}_{\mathrm{x}}$ contributes an additional $2 \mathrm{ppb}$ to boundary layer ozone production, while snow sourced bromine has the opposite effect and contributes $1 \mathrm{ppb}$ to boundary layer ozone loss.

\section{Introduction}

Air-snow interactions are known to impact the composition of the polar boundary layer via deposition, chemical processing, and emission of chemical species (e.g. Dominé and Shepson, 2002; Grannas et al., 2007). Photochemistry on 
snow grains and in interstitial air (air between snow grains in the snowpack) lead, for example, to the formation of nitrogen oxides $\left(\mathrm{NO}_{\mathrm{x}}\right)$, formaldehyde $(\mathrm{HCHO})$, hydrogen peroxide $\left(\mathrm{H}_{2} \mathrm{O}_{2}\right)$, $\mathrm{HONO}$, and reactive halogen species, which can then be released into the boundary layer above the snowpack. This release has been observed at Summit station (e.g. Hutterli et al., 1999, 2001; Honrath et al., 1999, 2002; Dibb et al., 2002, 2010; Jacobi et al., 2004; Sjostedt et al., 2007; Liao et al., 2011; Stutz et al., 2011) in the center of the Greenland ice sheet and in Antarctica (e.g. Davis et al., 2001; Jones et al., 2001), where concentrations of $\mathrm{NO}_{\mathrm{x}}$ and other species far exceed those expected from gas phase and aerosol chemistry alone.

Fluxes of $\mathrm{NO}_{\mathrm{x}}$ from surface snow into a shallow boundary layer have been shown to cause photochemical ozone production in Antarctica (e.g. Crawford et al., 2001; Helmig et al., 2008). In the center of the Greenland ice sheet, where $\mathrm{NO}_{\mathrm{x}}$ fluxes have also been observed, large increases in boundary layer ozone similar to those observed at South Pole have not been directly measured (Dibb et al., 2002; Honrath et al., 1999, 2000, 2002). Constrained chemical box model calculations have shown that the reaction of $\mathrm{NO}$ and $\mathrm{RO}_{2}$ in the boundary layer at Summit should result in ozone production (Sjostedt et al., 2007).

Rather than ozone production, it has been shown at Summit that ozone depletion occurs via either chemical or physical processes in the snowpack (Peterson and Honrath, 2001). The presence of reactive bromine at Summit has recently been confirmed (Dibb et al., 2010; Stutz et al., 2011; Liao et al., 2011) and most likely contributes to ozone destruction. Although, bromine is present at Summit in much lower concentrations than typically found in the coastal Arctic (summarized in Simpson et al., 2007 and Abbatt et al., 2012). Observations of interstitial ozone show that mixing ratios decrease in the snowpack relative to boundary layer (Peterson and Honrath, 2001), suggesting that ozone is predominantly deposited or chemically destroyed in snow (e.g. Helmig et al., 2007). Ozone depletion in the interstitial air suggests that bromine chemistry is more active in the snowpack (Peterson and Honrath, 2001; Helmig et al., 2002), implying a snow source of reactive bromine at Summit.

Snow sourced species may also produce additional $\mathrm{HO}_{\mathrm{x}}$ radicals and perturb the $\mathrm{OH}: \mathrm{HO}_{\mathrm{x}}$ ratio via faster/additional $\mathrm{HO}_{\mathrm{x}}$ interconversion reactions (e.g. Yang et al., 2002; Chen et al., 2007; Liao et al., 2011). Measurements have suggested that $\mathrm{HONO}$, an important $\mathrm{OH}$ precursor, is released from the remote snowpack (Zhou et al., 2001; Dibb et al., 2002; Honrath et al., 2002; Bartels-Rausch and Donaldson, 2006) and from frozen nitrate in ice upon irradiation (Anastasio and $\mathrm{Chu}, 2009$ ). Snowpack emissions of $\mathrm{HCHO}$ and $\mathrm{H}_{2} \mathrm{O}_{2}$ have also been measured (Hutterli et al., 1999; Jacobi et al., 2004; Hutterli et al., 2001; Sumner et al., 2002; Barret et al., 2011) and largely attributed to temperature induced cycling caused by radiative heating and cooling of the snow surface (Hutterli et al., 2001). These species may also be important be- cause they result in additional $\mathrm{HO}_{\mathrm{x}}\left(\mathrm{HO}_{\mathrm{x}}=\mathrm{OH}+\mathrm{HO}_{2}\right)$ formation upon photolysis. Indirect evidence for the impact of halogen chemistry on $\mathrm{HO}_{\mathrm{x}}$ levels at Summit, Greenland was provided by unusually high $\mathrm{OH}:\left(\mathrm{HO}_{2}+\mathrm{RO}_{2}\right)$ ratios that have been measured during summer (Sjostedt et al., 2007; Liao et al., 2011). Prior modeling work using a constrained box model showed the importance of these species for $\mathrm{OH}$ budget at Summit (Chen et al., 2007).

While it has been clearly demonstrated that snow photochemistry influences the lower atmosphere, few attempts have been made to provide a quantitative physical and chemical description of the air-snow system. In particular, there is a need for studies that show how in-snow photochemistry and transport impact boundary layer radical and ozone chemistry. In this study, we will address this using a detailed 1-D snowatmosphere chemistry and transport model (Thomas et al., 2011). The model will be applied to the conditions during the Greenland Summit Halogen- $\mathrm{HO}_{\mathrm{x}}$ (GSHOX) Campaign at Summit, Greenland $\left(72^{\circ} 34^{\prime} \mathrm{N}, 38^{\circ} 29^{\prime} \mathrm{W}\right.$, altitude $\left.=3.2 \mathrm{~km}\right)$, where $\mathrm{HO}_{\mathrm{x}}$ and halogen cycling was studied in summer 2008. Ground based measurements, including hydroxyl and peroxy radicals $\left(\mathrm{OH}\right.$ and $\left.\mathrm{HO}_{2}+\mathrm{RO}_{2}\right)$, ozone $\left(\mathrm{O}_{3}\right)$, nitrogen oxide (NO), mistchamber nitrite (soluble $\mathrm{NO}_{2}^{-}$), and bromine oxide (BrO), will be compared to model results. The model output for a base case and for several sensitivity runs is used to quantify how in-snow photochemistry of $\mathrm{NO}_{\mathrm{x}}, \mathrm{HONO}$, and bromine impact the oxidation capacity of the boundary layer. We will also investigate how this chemistry impacts ozone formation over snow.

\subsection{Atmospheric radical and ozone chemistry}

It is instructive to begin a study of this system with a short review on how snow photochemistry can change boundary layer gas phase $\mathrm{HO}_{\mathrm{x}}$ and ozone chemistry. The Arctic is a unique region where photolysis rates are enhanced by the high surface albedo over snow. Therefore, photolysis rates in the snow covered Arctic can be comparable to those at lower latitudes, despite the higher solar zenith angles encountered in polar regions (which would normally result in lower photolysis rates without snow cover). The primary $\mathrm{OH}$ source in the atmosphere is reaction of $\mathrm{O}\left({ }^{1} \mathrm{D}\right)$, which results from ozone photolysis (Reaction R1), with gas phase water (Reaction R2).

$\mathrm{O}_{3}+h v(\lambda<340 \mathrm{~nm}) \rightarrow \mathrm{O}\left({ }^{1} \mathrm{D}\right)+\mathrm{O}_{2}$

$\mathrm{O}\left({ }^{1} \mathrm{D}\right)+\mathrm{H}_{2} \mathrm{O} \rightarrow 2 \mathrm{OH}$

HONO and $\mathrm{H}_{2} \mathrm{O}_{2}$, both of which are known to be released from the snowpack, can also be significant sources of $\mathrm{OH}$ (Reactions R3 and R4).

$\mathrm{HONO}+h v \rightarrow \mathrm{OH}+\mathrm{NO}$

$\mathrm{H}_{2} \mathrm{O}_{2}+h v \rightarrow 2 \mathrm{OH}$ 


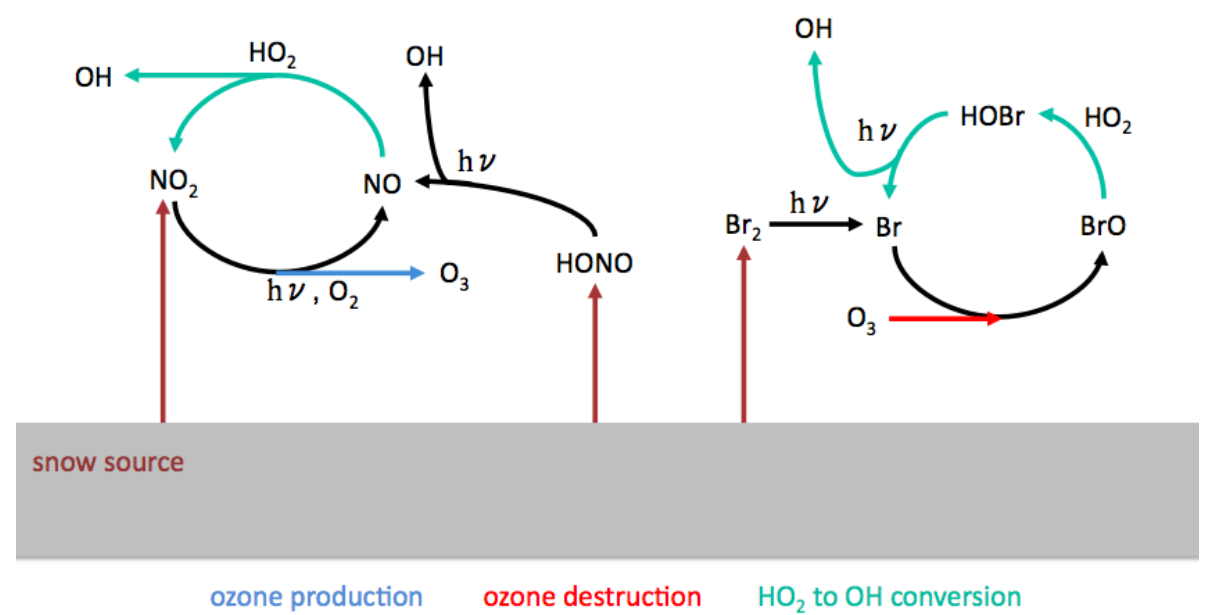

Fig. 1. Schematic of snow sourced $\mathrm{NO}_{\mathrm{x}}, \mathrm{HONO}$, and bromine and their impact on ozone production and destruction. The figure also captures the impact of snow emissions on $\mathrm{OH}$. Both $\mathrm{NO}_{\mathrm{x}}$ and bromine cycling shift the $\mathrm{OH}: \mathrm{HO}_{2}$ ratio towards $\mathrm{OH}$. Snow sourced $\mathrm{HONO}$ is a direct source of $\mathrm{OH}$.

The photolysis of $\mathrm{HCHO}$ released from the snow forms $\mathrm{HO}_{2}$ radicals, which can increase $\mathrm{HO}_{\mathrm{x}}$ levels.

$\mathrm{HCHO}+h v \stackrel{\left[\mathrm{O}_{2}\right]}{\rightarrow} 2 \mathrm{HO}_{2}+\mathrm{CO}$

In remote polar regions, $\mathrm{OH}$ is converted to both $\mathrm{HO}_{2}$ and $\mathrm{RO}_{2}$ predominantly via reactions with $\mathrm{CO}$, methane, and, to a minor extent, other organics. The most important $\mathrm{OH}$ loss reactions are with $\mathrm{CO}$ and methane (Reactions R6 and R7).

$\mathrm{CO}+\mathrm{OH} \stackrel{\left[\mathrm{O}_{2}\right]}{\rightarrow} \mathrm{HO}_{2}+\mathrm{CO}_{2}$

$\mathrm{CH}_{4}+\mathrm{OH} \stackrel{\left[\mathrm{O}_{2}\right]}{\rightarrow} \mathrm{CH}_{3} \mathrm{O}_{2}+\mathrm{H}_{2} \mathrm{O}$

Methane and $\mathrm{CO}$ are not known to be influenced directly by the snow and their main sources are long-range transport to the remote Arctic or Antarctica. $\mathrm{NO}_{\mathrm{x}}$ is also important for $\mathrm{HO}_{\mathrm{x}}$ cycling, but is subject to loss during long-range transport to the remote Arctic, making even small local $\mathrm{NO}_{\mathrm{x}}$ sources important. At levels above $10-20 \mathrm{ppt} \mathrm{NO}_{\mathrm{x}}$ plays a key role in determining the ratio of $\mathrm{OH}$ to $\mathrm{HO}_{2}$ because of conversion of the hydroperoxyl radical back to $\mathrm{OH}$ (Reaction R8).

$\mathrm{NO}+\mathrm{HO}_{2} \rightarrow \mathrm{NO}_{2}+\mathrm{OH}$

Conversion of $\mathrm{RO}_{2}$ to $\mathrm{HO}_{2}$ can also occur. For example, $\mathrm{NO}$ reacts with the methyl peroxy radical and $\mathrm{O}_{2}$ to form formaldehyde (HCHO) and $\mathrm{HO}_{2}$ (Reaction R9).

$\mathrm{NO}+\mathrm{CH}_{3} \mathrm{O}_{2} \stackrel{\left[\mathrm{O}_{2}\right]}{\rightarrow} \mathrm{NO}_{2}+\mathrm{HCHO}+\mathrm{HO}_{2}$

These reactions compete with the self and cross reaction of $\mathrm{HO}_{2}$ and $\mathrm{RO}_{2}$ to form peroxides, for example Reactions (R10) and (R11).

$\mathrm{HO}_{2}+\mathrm{HO}_{2} \rightarrow \mathrm{H}_{2} \mathrm{O}_{2}+\mathrm{O}_{2}$
$\mathrm{RO}_{2}+\mathrm{HO}_{2} \rightarrow \mathrm{ROOH}+\mathrm{O}_{2}$

The levels of $\mathrm{NO}_{\mathrm{x}}$ are crucial in determining whether the $\mathrm{OH} / \mathrm{HO}_{2}$ cycle is propagated (Reaction R8) or terminated.

Because the photolysis of $\mathrm{NO}_{2}$, followed by the reaction of the oxygen atom with $\mathrm{O}_{2}$, is the only chemical source of ozone in the troposphere the levels of $\mathrm{NO}_{\mathrm{x}}$ determine the ozone formation rate in the troposphere.

$\mathrm{NO}_{2}+h v(\lambda<340 \mathrm{~nm}) \rightarrow \mathrm{NO}+\mathrm{O}$

$\mathrm{O}+\mathrm{O}_{2} \rightarrow \mathrm{O}_{3}$

The formation and release of $\mathrm{NO}_{\mathrm{x}}$ from the snowpack, which substantially increases surface $\mathrm{NO}$ and $\mathrm{NO}_{2}$ levels, is therefore important for determining both the oxidative capacity of the boundary layer as well as ozone concentrations.

In the presence of reactive bromine, which can also be released from the snow, additional reactions can impact the cycling of $\mathrm{HO}_{\mathrm{x}}$ and the $\mathrm{OH} / \mathrm{HO}_{2}$ ratio:

$\mathrm{BrO}+\mathrm{HO}_{2} \rightarrow \mathrm{HOBr}+\mathrm{O}_{2}$

$\mathrm{HOBr}+h v \rightarrow \mathrm{Br}+\mathrm{OH}$

$\mathrm{Br}+\mathrm{O}_{3} \rightarrow \mathrm{BrO}$

The reaction cycle (R14)-(R16) is also known to destroy ozone, and is the dominant bromine catalyzed ozone destruction mechanism at $\mathrm{BrO}$ levels below $5 \mathrm{ppt}$. The Reactions (R14) and (R15) together convert $\mathrm{HO}_{2}$ to $\mathrm{OH}$.

It is also known that $\mathrm{HCHO}$ can play a role in halogen recycling, via reaction of $\mathrm{BrO}$ with $\mathrm{HCHO}$ to form $\mathrm{HOBr}$ (Reaction R17) as pointed out by Michalowski et al. (2000).

$\mathrm{BrO}+\mathrm{HCHO} \stackrel{\left[\mathrm{O}_{2}\right]}{\rightarrow} \mathrm{HOBr}+\mathrm{CO}+\mathrm{HO}_{2}$ 
$\mathrm{HOBr}$ formed by either Reaction (R14) or (R17) can be taken up on aerosol particles or snow grains and contributes to $\mathrm{Br}_{2}$ recycling.

This brief review shows how both nitrogen and halogen chemistry modify the fundamental radical cycles that determine ozone and $\mathrm{OH}$ concentrations in the troposphere. Figure 1 shows the main pathways by which emissions of reactive bromine and nitrogen oxides from snow impact ozone and $\mathrm{OH}$. Snow sourced $\mathrm{NO}_{\mathrm{x}}$ contributes to ozone production, while bromine destroys ozone via a well known catalytic cycle. Both $\mathrm{NO}_{\mathrm{x}}$ and bromine shift the $\mathrm{OH}: \mathrm{HO}_{2}$ ratio towards $\mathrm{OH}$. $\mathrm{HONO}, \mathrm{H}_{2} \mathrm{O}_{2}$, and $\mathrm{HCHO}$ emitted from the snowpack produce additional $\mathrm{OH}$ upon photolysis, therefore also increasing the amount of $\mathrm{OH}$ in the boundary layer. The connections between $\mathrm{HO}_{\mathrm{x}}+\mathrm{RO}_{2}$ cycling and $\mathrm{H}_{2} \mathrm{O}_{2}, \mathrm{HCHO}$, halogens, $\mathrm{HONO}$, and $\mathrm{NO}_{\mathrm{x}}$ show that these processes cannot be considered separately, therefore we discuss the predicted concentrations of these species in the context of current and past measurements at Summit.

\subsection{Snow chemistry and physics}

To fully describe the coupled snow-air system, chemistry occurring in snowpack needs to be treated explicitly. We use a simplified representation of the liquid-like layer (LLL) and its chemistry to represent the complex, but poorly understood, processes occuring in the snowpack. The modeled LLL is a disordered liquid-like interfacial layer on ice, which is a combination of the quasi-liquid layer (QLL) and brine layers (BL), which form for fundamentally different reasons (e.g. Kuo et al., 2011). The QLL is a disordered layer of waters at the surface of ice that forms even at very low or no impurity concentrations. On the other hand, brine pockets (BL) with high impurity concentrations form in ice with higher solute content. Both the QLL and BL should in principal grow with increased impurities and temperature. Given that there is a great deal of uncertainty that surrounds how to correctly represent the LLL in models, we represent the LLL and its chemistry in a simplified way. Our representation of snow chemistry will require improvements in the future as our understanding of both LLL physics and chemistry develops. In this section we differentiate between liquid-like and gas phase species by using the subscript (LLL) to refer to species in the liquid-like layer at the surface of snow grains. A description of the model has already been presented in Thomas et al. (2011), therefore the chemistry and physics will only be briefly reviewed here.

The source of $\mathrm{NO}_{\mathrm{x}}$ and HONO in the snowpack is the photolysis of nitrate and reactions involving nitrite in a LLL on the snow grain surface (Reactions R18-R22).

$$
\begin{aligned}
& \mathrm{NO}_{3(\mathrm{LLL})}^{-}+h v \rightarrow \mathrm{NO}_{2(\mathrm{LLL})} \\
& \mathrm{NO}_{3(\mathrm{LLL})}^{-}+h v \rightarrow \mathrm{NO}_{2(\mathrm{LLL})}^{-}+\mathrm{O} \\
& \mathrm{NO}_{2(\mathrm{LLL})} \rightarrow \mathrm{NO}_{2}
\end{aligned}
$$

$$
\mathrm{H}_{(\mathrm{LLL})}^{+}+\mathrm{NO}_{2(\mathrm{LLL})}^{-} \leftrightarrow \mathrm{HONO}_{(\mathrm{LLL})}
$$

$\mathrm{HONO}_{(\mathrm{LLL})} \rightarrow \mathrm{HONO}$

The resulting $\mathrm{NO}_{2}$ and $\mathrm{HONO}$ in the firn air undergo gas phase photochemical reactions as they are transported to the boundary layer by both diffusion and wind pumping, as discussed in Liao and Tan (2008) for HONO.

Model results have shown that $\mathrm{BrO}$ measured in the boundary layer at Summit during summer 2008 can result from photochemical release of bromide impurities in snow (Thomas et al., 2011). Photochemical production of $\mathrm{Br}_{2}$ in a LLL that covers snow grains results in halogen release from the snowpack (Reactions R23 and R24). BrO in both interstitial air and the atmosphere is formed from photolysis of $\mathrm{Br}_{2}$ (Reaction R25) followed by reaction with ozone (R16).

$$
\begin{aligned}
& \mathrm{Br}_{(\mathrm{LLL})}^{-}+h v \rightarrow \rightarrow \rightarrow \mathrm{Br}_{2(\mathrm{LLL})} \\
& \mathrm{Br}_{2(\mathrm{LL})} \rightarrow \mathrm{Br}_{2} \\
& \mathrm{Br}_{2}+h v \rightarrow 2 \mathrm{Br}
\end{aligned}
$$

The chemical cycling of bromine and nitrogen species is directly connected via a number of chemical reactions. For example, in the gas phase $\mathrm{BrO}$ reacts with both $\mathrm{NO}$ and $\mathrm{NO}_{2}$ (Reactions R26 and R27).

$$
\begin{aligned}
& \mathrm{BrO}+\mathrm{NO} \rightarrow \mathrm{Br}+\mathrm{NO}_{2} \\
& \mathrm{BrO}+\mathrm{NO}_{2} \stackrel{[\mathrm{M}]}{\rightarrow} \mathrm{BrNO}_{3}
\end{aligned}
$$

In the condensed phase, bromine and nitrogen species also react (for example Reaction R28)

$$
\mathrm{Br}_{2(\mathrm{LLL})}^{-}+\mathrm{NO}_{2(\mathrm{LLL})}^{-} \rightarrow 2 \mathrm{Br}_{(\mathrm{LLL})}^{-}+\mathrm{NO}_{2(\mathrm{LLL})}
$$

Hydrogen peroxide $\left(\mathrm{H}_{2} \mathrm{O}_{2}\right)$ and formaldehyde ( $\mathrm{HCHO}$ ) experience strong summertime cycling over the snowpack driven by temperature-induced uptake and release, which likely involves diffusion between the gas phase and solid ice matrix within snow grains (Barret et al., 2011; Hutterli et al., 1999, 2001). In the present study, we do not treat the solid diffusion process. Therefore, it is likely that we only capture a portion of this temperature driven cycling. These species are also photochemically produced and destroyed, which we model explicitly in the LLL and interstitial air using a simple chemical mechanism.

Another crucial process in understanding the impact of snow chemistry on the atmosphere is how efficiently ambient and interstitial air are exchanged. This process is still poorly constrained, as discussed in our previous study (Thomas et al., 2011). We use a parameterization including both gas phase diffusion and wind pumping (Cunningham and Waddington, 1993), combined with horizontal and vertical relief structure and a constant wind speed of $3 \mathrm{~m} \mathrm{~s}^{-1}$, which led to an accurate description of surface trace gas mixing ratios in Thomas et al. (2011). We use the same parameters in 
this study, however it should be noted that wind pumping has a large influence on surface layer trace gas mixing ratios and needs further study.

It is also essential to capture the effect of boundary layer vertical mixing processes as the boundary layer height determines concentrations of gases released from the snow (Anderson and Neff, 2008). Correctly modeling boundary layer mixing processes requires considering the high albedo and radiative heating that rapidly warms the boundary layer at solar noon in snow covered regions, which we model by constraining the snow surface temperature to measurements. The impact of boundary layer mixing at Summit was recently discussed in the context of $\mathrm{BrO}$ and $\mathrm{NO}$ measurements in Part 1 of this work (Thomas et al., 2011).

The correct description of the gas phase and surface/aerosol chemistry in the atmosphere and the snowpack, as well as the accurate quantification of the vertical transport processes in and above the snow are crucial for a correct description of the snow-air system in remote polar regions. The approach we employ is based on describing the coupled system using first principles by employing a 1-D chemistry and transport snow-atmosphere model (Sect. 2) that is compared with surface observations (Sect. 3). Through sensitivity runs and an analysis of the various chemical pathways, we will then investigate the budget of $\mathrm{OH}, \mathrm{HO}_{2}+\mathrm{RO}_{2}$, and ozone (Sect. 4).

\section{Description of the model and overview of runs}

To model coupled snow-atmosphere chemistry and physics, we use the model MISTRA-SNOW with an initialization chosen for Summit, Greenland for comparison with measurements taken in June 2008. For a detailed description of the model, methodology, and initialization we refer the reader to the companion paper (Thomas et al., 2011). The model includes a 1-D vertical grid in the snowpack and the atmosphere. The snow/firn is represented as a one-dimensional vertical $\log$ scale grid to a depth of $3 \mathrm{~m}$ with a total of 20 grid cells. The atmosphere is represented by an evenly spaced grid with $1 \mathrm{~m}$ vertical grid spacing in the lowest $100 \mathrm{~m}$ and a logarithmically spaced grid from $100-2000 \mathrm{~m}$.

Observations from the local airmass period during GSHOX 2008 and well known background concentrations were used to initialize the model run. The vertical mixing in the atmosphere and the extent of the boundary layer was simulated solely by constraining the surface temperature. The simulated temperature profiles showed excellent agreement with the observations (Thomas et al., 2011). Besides surface temperature, only the partitioning of nitrate and bromide between the bulk snow and LLL were adjusted in the model, which are not well characterized.. The adjustment was performed such that the modeled surface levels of $\mathrm{NO}$ and $\mathrm{BrO}$ agreed with the observations. The best agreement was found for LLL nitrate being $6 \%$ of total nitrate measured in melted snow. In the case of bromide (and chloride) $100 \%$ of the bulk snow ions were initialized in the LLL.

We represent the snowpack using spherical snow grains covered by a uniform $10 \mathrm{~nm}$ thick liquid layer (summarized in Rosenberg, 2005) in which chemistry occurs. We have chosen a liquid layer thickness in the mid-range of QLL measurements for pure ice in the temperature range of the model. Exactly how to represent the QLL and BL in models of snow chemistry is still under discussion, despite recent progress (Kuo et al., 2011). For the low ion concentrations at Summit, it's not clear if a true BL forms. According to Kuo et al. (2011) for a known melt concentration, very little or no brine formation is predicted for the solute concentrations measured in surface snow at Summit, which is consistent with the model initialization. We initialize the model using a snow grain radius $(1 \mathrm{~mm})$ and density $\left(\rho=0.3 \mathrm{~g} \mathrm{~cm}^{-3}\right)$. Liquid water content was calculated based on density, snow grain radius, and liquid layer thickness.

The model treats gas and aqueous chemistry in the atmosphere and snowpack as well as transfer between the gas and aqueous phases, heterogeneous reactions on aerosols are included in the boundary layer. A complete list of reactions, including both the gas and aqueous phases as well as the Henry's law constants and mass accommodation coefficients, are included in the electronic supplement of Thomas et al. (2011). Photolysis rates in the snowpack decrease exponentially with depth due to decreasing light penetration with depth in the snowpack. We use an $e$-folding depth of $\epsilon_{\lambda}=10 \mathrm{~cm}$, measured for nitrate at Summit, Greenland (Galbavy et al., 2007) for all species that undergo photolysis to describe how photolysis rates decay with depth in the snowpack.

The base case model run is initialized with gas and aqueous phase concentrations as described in Thomas et al. (2011), Table 2. Briefly, the initial gas phase mixing ratios in the interstitial air are vertically uniform for species with long atmospheric lifetimes (for example $\mathrm{CO}$ ) and decay with snow depth for reactive species (for example $\mathrm{O}_{3}$, $\mathrm{H}_{2} \mathrm{O}_{2}$, and $\mathrm{HCHO}$ ). Aqueous phase concentrations are initially equal to the Henry's law equilibrium concentration for volatile species. For non-volatile species (ions) the initial concentration is equal to $C_{\mathrm{LLL}}=\phi \times C_{\text {snow }}$, where $C_{\text {snow }}$ is the concentration in melted surface snow measured by liquid ion chromatography at Summit during the days chosen for the model runs and $\phi$ is a factor that relates this measured concentration to the LLL concentration in the model.

We assume $\mathrm{HNO}_{3}$ uptake to be the major source of liquid layer acidity, therefore we use the initial nitrate concentration in the LLL $\left(C_{\mathrm{LLL}}\right)$ to determine the initial $\mathrm{H}^{+}$concentration such that $C_{\mathrm{LLL}}\left(\mathrm{NO}_{3}^{-}\right)=C_{\mathrm{LLL}}\left(\mathrm{H}^{+}\right)$. The atmospheric aerosol number and size distribution was initialized by parameterizing aerosol size distribution measurements at Summit on 12 June 2008.

The focus of this paper is to investigate the impact of snow sourced trace gases on the oxidation capacity of the boundary 
Table 1. Liquid layer concentrations for the base case and sensitivity model runs conducted based on measurements taken in June 2008 as well as previous measurements at Summit, Greenland.

\begin{tabular}{|c|c|c|c|c|}
\hline \multicolumn{5}{|c|}{ LLL concentration $(\mathrm{M})$} \\
\hline Species & base case $\mathrm{c}^{\mathrm{a}}$ & no bromide (noBro) & no nitrate (noNit) & Reference \\
\hline $\mathrm{Br}^{-}$ & $3.3 \times 10^{-4}$ & 0 & base case conc. & Dibb et al. (2010) \\
\hline $\mathrm{Cl}^{-}$ & $1.8 \times 10^{-2}$ & base case conc. & base case conc. & Dibb et al. (2010) \\
\hline $\mathrm{NO}_{3}^{-}$ & $8.8 \times 10^{-3}$ & base case conc. & 0 & Dibb et al. (2010) \\
\hline $\mathrm{H}^{+}{ }^{3}$ & $8.8 \times 10^{-3}$ & base case conc. & base case conc. & equal to nitrate ${ }^{b}$ \\
\hline $\mathrm{Na}^{+}$ & $1.9 \times 10^{-2}$ & base case conc. & base case conc. & counter ion $^{\mathrm{c}}$ \\
\hline $\mathrm{HCHO}$ & $2.0 \times 10^{-5}$ & base case conc. & base case conc. & $\begin{array}{l}\text { Henry's law based on } \\
\text { Chameides (1984) }\end{array}$ \\
\hline $\mathrm{H}_{2} \mathrm{O}_{2}$ & $1.0 \times 10^{-3}$ & base case conc. & base case conc. & $\begin{array}{l}\text { Henry's law based on } \\
\text { Lind and Kok (1994) }\end{array}$ \\
\hline
\end{tabular}

layer using a set of sensitivity runs. We have completed runs with the initial bromide in the liquid layer set to zero (referred to as noBro) and with the initial nitrate in the liquid layer set to zero (referred to as noNit). The liquid layer initialization for the base case and the two sensitivity runs is summarized in Table 1.

\section{Summary of measurements}

To further interpret and evaluate our model results we will compare them to a number of observations during the GSHOX experiment. Most of these measurements have already been published and we will only give a brief overview here. We will focus here on the periods when FLEXPART (Stohl et al., 2005) emission sensitivities showed that the observed airmass resided over the Greenland Ice Sheet at least 3 days prior to the observations at Summit (Stutz et al., 2011). The restriction to these local airmasses reduces the effect of advection and also removes meteorological biases.

Observation of $\mathrm{OH}$ and $\mathrm{HO}_{2}+\mathrm{RO}_{2}$ radicals were performed by Chemical Ionization Mass Spectrometry (CIMS) $1.5 \mathrm{~m}$ above the snow surface as described by Liao et al. (2011). OH values showed the typical diurnal variation with mid-day median $\mathrm{OH}$ values of $6 \times 10^{6}$ molecules $\mathrm{cm}^{-3}$ (detection limit of $1 \times 10^{5}$ molecules $\mathrm{cm}^{-3}$ ) and concentration close to zero at night, with variations of around $30 \%$. $\mathrm{HO}_{2}+\mathrm{RO}_{2}$ values were $5 \times 10^{8}$ molecules $\mathrm{cm}^{-3}$ (detection limit of $1 \times 10^{7}$ molecules $\mathrm{cm}^{-3}$ ) and followed the diurnal behavior seen for $\mathrm{OH}$. Liao et al. (2011) report the combined uncertainties of the CIMS as $\sim 30 \%$ for $\mathrm{OH}$ measurements and $\sim 35 \%$ for $\mathrm{HO}_{2}+\mathrm{RO}_{2}$ measurements, predominantly due to the uncertainty in the instrument calibration.

NO was measured using a standard chemiluminescence technique with an accuracy of $\pm 10 \%$ and a detection limit of $<3$ ppt (Liao et al., 2011). The NO inlet was placed close to the other in-situ measurements during GSHOX at around $1.5 \mathrm{~m}$ height above the snow. It should be noted that the NO data, as well as other datasets used here were filtered for the influence of the emissions from Summit station, which typically increase NO levels during northerly winds. Ozone was measured by UV-absorption with an accuracy of better than $\pm 5 \%$ (detection limit $<1 \mathrm{ppb}$ ) close to the other in-situ inlets (Liao et al., 2011).

Actinic fluxes above the snow were measured by a $2 \pi$ Scanning Actinic Flux Spectrometer (SAFS) (Shetter and Müller, 1999) operated by the University of Houston near the sampling location. The impact of the snow albedo was determined by intermittently turning the SAFS downward. The photolysis rates of various atmospheric compounds were then calculated based on downwelling flux and a correction factor that considered the reflection from the snow surface. The accuracy of the actinic flux measurements are on the order of $6 \%$ in the UV-B and $5 \%$ in the UV-A and precision of the measurements was $3 \%$ for the UV-B and $2 \%$ for the UV-A wavelength regions. The majority of the uncertainty in the photolysis frequencies calculated using the actinic flux measurements comes from the uncertainty in either the molecular absorption cross-section or the photolysis quantum yield, consequently the overall uncertainty for the individual $J$-values is typically $12-18 \%$. Due to the high snow albedo and high elevation at Summit the photolysis rates were comparable to those typically found at lower latitudes. In addition, it should be noted that due to the northern latitude of Summit the sun did not set at night and thus photolysis continued, albeit at low rates, at night. The measured photolysis rates were predominantly used to evaluate the model representation of HONO photolysis.

Water soluble gas phase species were measured by mistchamber samplers and near-real-time by ion 


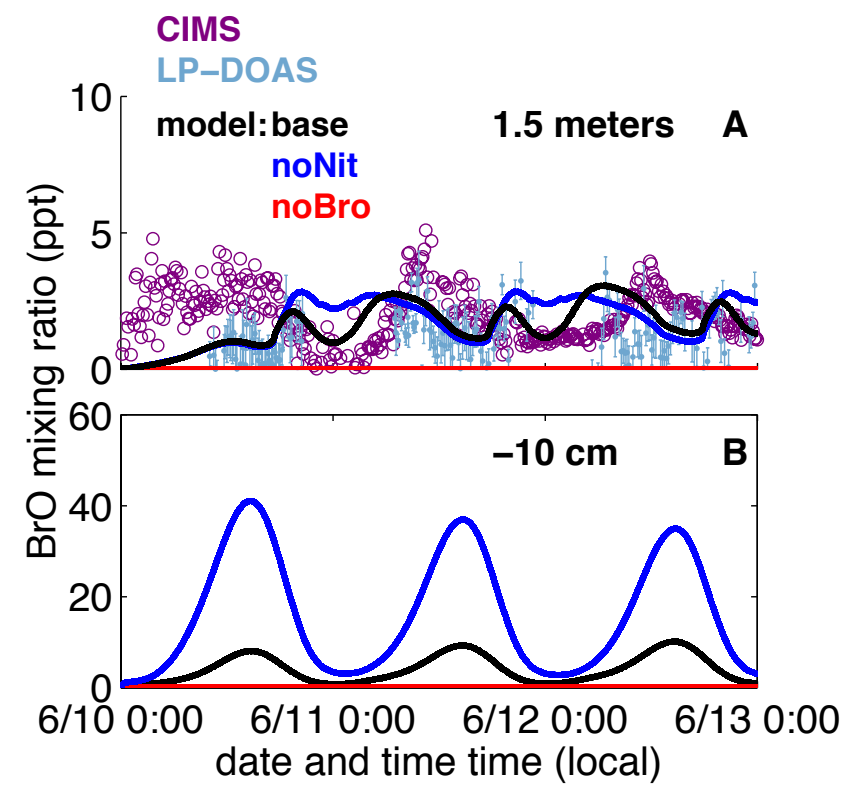

Fig. 2. Model predicted $\mathrm{BrO}$ for a three day model run for the base, noNit, and noBro cases compared to measurements of $\mathrm{BrO}$ using CIMS and LP-DOAS techniques during 10-13 June 2008. Without bromide in the liquid layer, no $\mathrm{BrO}$ is predicted showing that snow sourced bromine is the only source of reactive halogens in the model. Without snow sourced $\mathrm{NO}_{\mathrm{x}}$ the amount of $\mathrm{BrO}$ predicted increases due to bromine loss processes that involve $\mathrm{NO}_{\mathrm{X}}$ in the gas phase.

chromatography (MC/IC) during the campaign as described by Dibb et al. (2010). Here we focus mostly on the soluble nitrite observations in and above snow. During the local airmass periods ambient soluble nitrite mixing ratios typically reached maxima of $\sim 7 \mathrm{ppt}$ around noon after increasing from typical nighttime levels of $\sim 2$ ppt. For the $27.5 \mathrm{~min}$ sample integration interval used at Summit the detection limits for the MC/IC system were $0.3 \mathrm{ppt}$. Uncertainty based on measured air and water volumes and precision of the concentrations determined by IC in sample solutions was $\pm(10 \%+0.1 \mathrm{ppt})$ for both nitric acid and soluble nitrite. The $\mathrm{MC} / \mathrm{IC}$ system was also used to sample interstitial air during some periods of the campaign and the inlet was placed $\sim 10 \mathrm{~cm}$ below the snow surface. The ion chromatograph was also used to determine the ionic composition of the surface snow as well as snow profiles at Summit during GSHOX 2008. Low levels of bromide and nitrate were found as described in detail by Dibb et al. (2010).

$\mathrm{BrO}$ was measured by two different instruments. A longpath Differential Optical Absorption Spectrometry system measured the $\mathrm{BrO}$ absorptions along two 2 or $4 \mathrm{~km}$ long open air absorption paths (Stutz et al., 2011). During the local air episodes in 2008 hourly averaged $\mathrm{BrO}$ mixing ratios were strongly modulated by solar radiation and boundary layer height, showing maxima of $\sim 1.5 \mathrm{ppt}$ in the morning and the evening with the LP-DOAS BrO detection limit during these

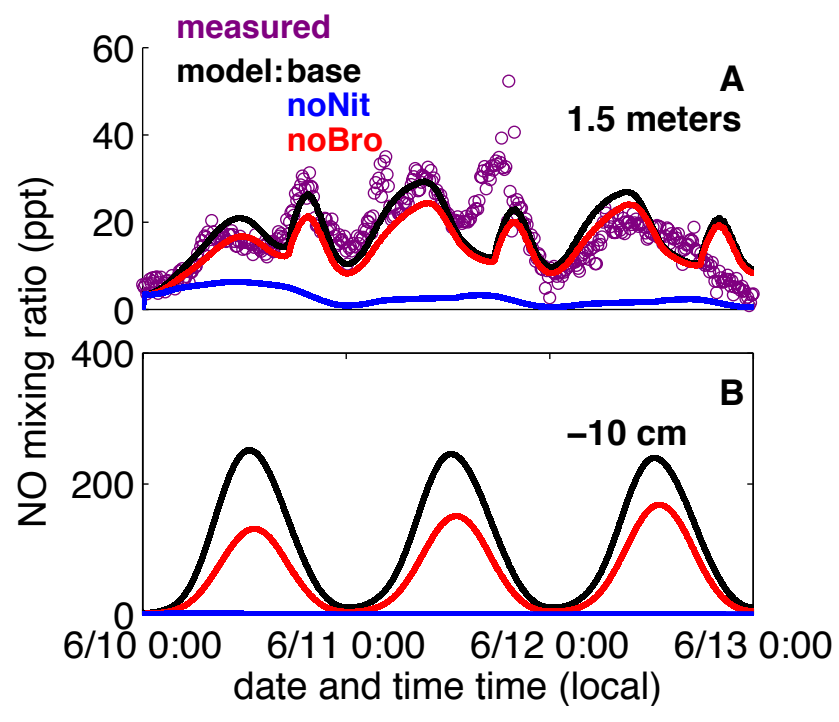

Fig. 3. Model predicted NO for a three day model run for the base, noNit, and noBro cases compared to measurements of NO taken on 10-13 June 2008. Without bromide in the liquid layer, the amount of $\mathrm{NO}$ predicted decreases. Without snow sourced $\mathrm{NO}_{\mathrm{x}}$ enhanced $\mathrm{NO}$ is not predicted in the interstitial air and ambient NO is predicted to be well below measured values.

times between $0.3-1 \mathrm{ppt}$ with an accuracy of 4-7\%. BrO was also measured at similar levels during these periods by CIMS which sampled close to the $\mathrm{OH} / \mathrm{HO}_{2}$ CIMS instrument (Liao et al., 2011). The accuracy of the CIMS BrO measurements is $\pm 30 \%-36 \%$ with an estimated detection limit of 1-2 ppt.

\section{Results and discussion}

We begin our investigation of boundary chemistry by further analyzing the results of the model run already discussed in Thomas et al. (2011), referred to as the base run in the present study. To gain additional insight we expand our analysis of the snow-atmosphere chemical system by comparing a sensitivity run without snow bromide (noBro) and a separate run without snow nitrate (noNit) to the base case. These runs will also be used to investigate the impact of snow nitrate and bromide on surface ozone. We also compare model predicted mixing ratios for other radical sources with current and prior measurements at Summit. The last part of this section is dedicated to a detailed analysis of $\mathrm{OH}, \mathrm{HO}_{2}$, and $\mathrm{RO}_{2}$ chemistry over snow.

\subsection{Bromine, $\mathrm{NO}_{\mathrm{x}}$, and HONO in the boundary layer}

Bromine and nitrogen chemistry are closely linked via chemistry in the gas and condensed phases. Using the sensitivity runs (noBrO and noNit) we investigate the links between snowpack chemistry and predicted reactive bromine (BrO) and nitrogen (NO) in the boundary layer. As expected, without snowpack bromide, no bromine is predicted in the 
boundary layer (Fig. 2). Similarly, without snowpack nitrate, little NO is predicted to remain in the boundary layer (Fig. 3).

The relationship between bromine and nitrogen chemistry is shown because without nitrate in the liquid layer the model predicts more $\mathrm{BrO}$ in both the ambient and interstitial air (Fig. 2a and b). Efficient formation of $\mathrm{BrNO}_{3}$ through the $\mathrm{BrO}+\mathrm{NO}_{2}$ reaction ( $\left.\mathrm{R} 26\right)$, results in an additional loss pathway for bromine with snow sourced $\mathrm{NO}_{\mathrm{x}}$. Without snow sourced $\mathrm{NO}_{\mathrm{x}}$, the partitioning of reactive gas phase bromine shifts from $\mathrm{BrNO}_{3}$ to $\mathrm{BrO}$ and additional reactive halogens are predicted.

In the interstitial air, where there is higher $\mathrm{NO}_{\mathrm{x}}$ than in the atmosphere, this effect is further amplified and there is significantly more $\mathrm{BrO}$ without $\mathrm{NO}_{\mathrm{x}}$ production in the snowpack (Fig. 2b). The reactions between bromine and nitrogen species in the gas phase are also important because $\mathrm{BrNO}_{3}$ has been shown to be a dominant source of nitrate deposited to surface snow in the coastal Arctic boundary layer (Morin et al., 2007, 2008), pointing to the importance of accurately understanding the connections between halogen and nitrogen cycling. Given this, one would expect that snow nitrate would strongly modulate $\mathrm{BrO}$ in the atmosphere and interstitial air and that lower $\mathrm{BrO}$ levels are expected in areas of high snow nitrate content.

The dependence of $\mathrm{NO}_{\mathrm{x}}$ chemistry on bromide in the liquid layer is more complicated because bromine and nitrate species also react in the LLL. $\mathrm{Br}_{2(\mathrm{LLL})}^{-}$, which is an important intermediate species in $\mathrm{Br}_{2(\mathrm{LLL})}$ production, also reacts quickly with $\mathrm{NO}_{2(\mathrm{LLL})}^{-}$producing $\mathrm{NO}_{2(\mathrm{LLL})}(\mathrm{R} 28)$. $\mathrm{NO}_{2(\mathrm{LLL})}$ is then transported to the gas phase (Reaction R20) where it undergoes photolysis to form NO. Reaction (R28) is in competition with the reaction of $\mathrm{NO}_{2(\mathrm{LLL})}^{-}$with $\mathrm{H}^{+}$forming $\mathrm{HONO}_{(\mathrm{LLL})}$ (Reaction R21), which can also escape into the gas phase and undergo photolysis forming NO. In the absence of bromide, the concentration of $\mathrm{NO}_{2(\mathrm{LLL})}$ is reduced because the reaction channel (Reaction R28) is turned off, thus resulting in a lower $\mathrm{NO}_{2}$ flux to the gas phase. This leads then to lower NO as reflected in (Fig. 3a and b). In the interstitial air NO mixing ratios halve in the absence of bromide during the first day.

The presence of bromide also influence the levels of HONO in the gas phase. Because HONO can be an important $\mathrm{OH}$ radical precursor, we also analyzed the model results for this species (Fig. 4). As expected from the competition between Reactions (R21) and (R28), HONO mixing ratios in the interstitial air double in the absence of snow bromide. Hence, the presence of bromine photochemistry in the condensed phase suppresses HONO formation by lowering the nitrite concentration (Reaction R28), which then changes $\mathrm{HONO}_{(\mathrm{aq})}$ formation rate (Reaction R21). A corresponding increase in boundary layer HONO is predicted for the noBro case (Fig. 4a).

The predicted HONO mixing ratios in all cases are significantly lower than the levels suggested by prior measurements at Summit (Honrath et al., 2002). Mistchamber measure-

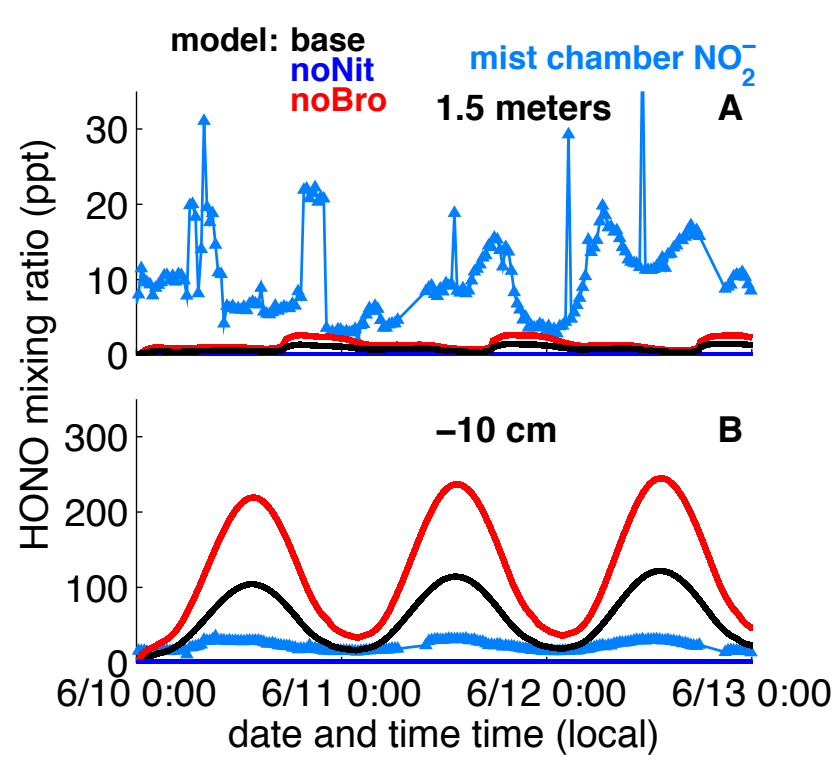

Fig. 4. Model predicted HONO for a three day model run (1013 June 2008) for the base, noNit, and noBro cases compared to mistchamber measurements of soluble nitrite with one inlet $1.5 \mathrm{~m}$ above the snow surface and one inlet $10 \mathrm{~cm}$ below the snow surface, sampling interstitial air.

ments above the snowpack averaged $\sim 10$ ppt of HONO during the GSHOX focus period, while the base case model run only predicts a maximum of between 1 and 2 ppt of HONO. The model predicts a large HONO source from snow photochemistry (Fig. 4), however HONO photolysis is faster than HONO can be replenished via transport upward from the snowpack. Consequently, the majority of HONO formed in the snowpack is photolyzed just below the snow surface and only small concentrations are predicted in the atmosphere.

We also compare the model predicted interstitial air HONO at a depth of $10 \mathrm{~cm}$ with mistchamber measurements taken with one inlet placed below the snow surface (Fig. 4b). While the measurements do predict enhanced nitrite below the surface, they do not approach the large values (100 ppt) predicted by the base case model run. A complicating factor in this comparison is that the mistchamber likely sampled a mix of interstitial and ambient air due to the large flow rate required for sampling.

To further investigate if the model predicted atmospheric HONO is reasonable, we analyzed the major source and loss terms for boundary layer HONO, which are transport from the snowpack and photolysis. The excellent agreement of observed and modeled boundary layer $\mathrm{NO}$ and $\mathrm{BrO}$ strongly support that the transport rate of species out of the snowpack is reasonable in the model. In addition, current work measuring NO in the interstitial air at Summit as discussed in Thomas et al. (2011), also indicates that snow-atmosphere exchange is described reasonably well in the model. The HONO photolysis rate calculated online by the model also 


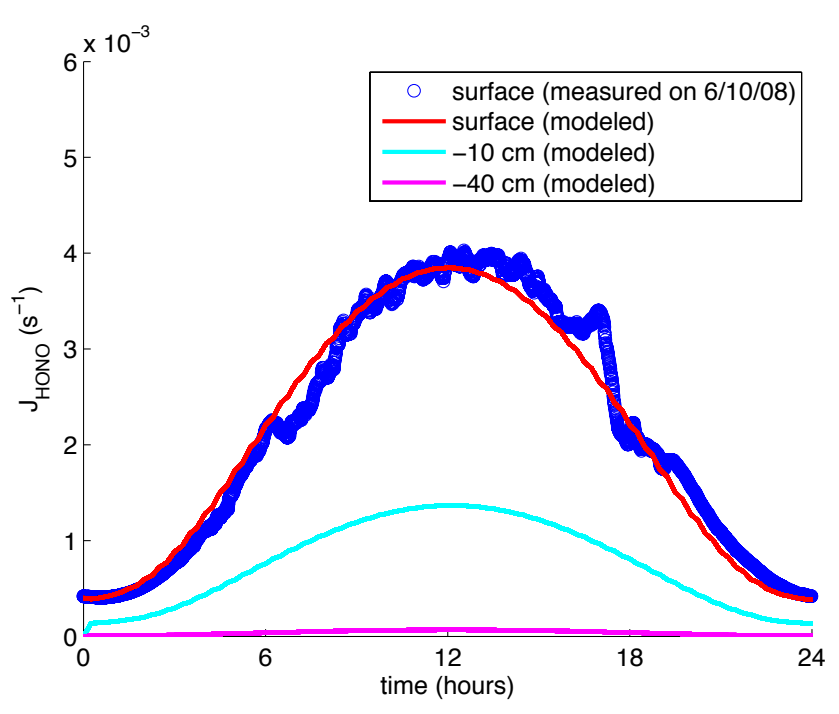

Fig. 5. Model predicted $J_{\mathrm{HONO}}$ on 10 June 2008 compared to the measured $J_{\mathrm{HONO}}$. The excellent agreement between ambient and measured $J_{\mathrm{HONO}}$ indicates that the rate of HONO loss in the boundary layer due to photolysis is correctly represented in the model. At the surface at solar noon the HONO lifetime is $4.4 \mathrm{~min}$, resulting in rapid photolysis to form $\mathrm{NO}$ and $\mathrm{OH}$.

shows excellent agreement with measurements at Summit from 10 June 2008 (Fig. 5). It is also feasible that the mistchamber technique samples another gas phase species as soluble nitrite $\left(\mathrm{NO}_{2}^{-}\right)$, which could explain the discrepancies between the model and measurements. However, HONO has also been observed at high levels in polar regions using a LOPAP instrument (LOng Path Absorption Photometer), which provides a specific measurement of HONO (Villena et al., 2011) and we have no clear evidence for such interfering species. We therefore, conclude that the most likely explanation for the observed elevated boundary layer HONO is a large missing HONO source. Any HONO source that is consistent with this study, would have to involve chemistry on atmospheric particles, in the gas phase, or chemistry occurring at the top of the snow-pack resulting in immediate release into the boundary layer. One example of a potential HONO source is photo-enhanced conversion of $\mathrm{NO}_{2}$ in the LLL involving HULIS (humic-like substances) present in the surface snow (Beine et al., 2008), which is not modeled here.

In summary, bromine and nitrogen chemistry are connected via chemical reactions in both the aqueous and gas phase. We have noted that bromine chemistry in the snowpack alters the ratio of $\mathrm{HONO}: \mathrm{NO}_{2}$ predicted by the model due to reactions between $\mathrm{NO}_{2(\mathrm{LLL})}^{-}$and $\mathrm{Br}_{2(\mathrm{LLL})}^{-}$. Bromine chemistry is primarily impacted via gas phase loss processes, which are faster when additional $\mathrm{NO}_{\mathrm{x}}$ is present.

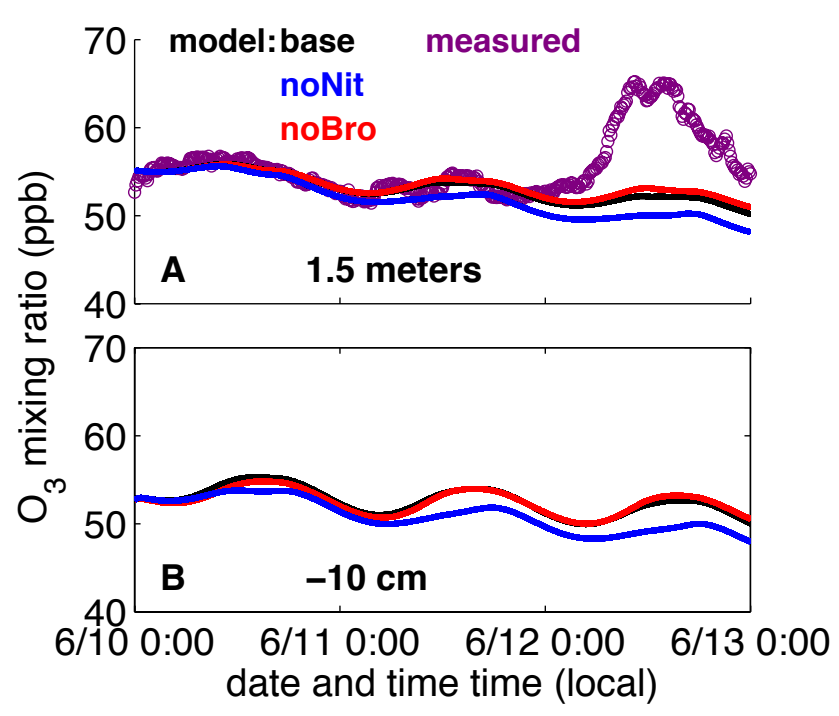

Fig. 6. Model predicted $\mathrm{O}_{3}$ compared to measurements above the snow surface for a three day model run (10-13 June 2008) for the base, noNit, and noBro cases.

\subsection{Influence of snow chemistry on ozone}

Ozone in the boundary layer is also impacted by snow photochemistry. In the coastal Arctic reactive bromine is known to cause large ozone depletion events, while on the Antarctic plateau, $\mathrm{NO}_{\mathrm{x}}$ emissions from snow cause large increases in ozone. At Summit, with lower levels of both bromine and $\mathrm{NO}_{\mathrm{x}}$, neither of these effects have been clearly observed. Given the opposing influence of $\mathrm{NO}_{\mathrm{x}}$ and bromine on ozone, we investigate their influences on ozone separately using sensitivity runs.

In the base case model run, with active halogen and $\mathrm{NO}_{\mathrm{x}}$ chemistry in the snowpack, measured ozone is reproduced well during the first two days (Fig. 6) as discussed in Thomas et al. (2011). The increase in observed ozone on the third day is caused by a change in airmass, which cannot be reproduced by our 1-D model. The influence of snow sourced $\mathrm{NO}_{\mathrm{x}}$ and bromine on ozone is shown in Fig. 6. In all three cases a decrease in ozone mixing ratios is predicted, both in ambient and interstitial air. The comparison of the base and the noNit case shows that nitrate snow chemistry leads to the formation of an additional 2-3 ppb in the boundary layer. A comparison of ozone formation, given by the rate of the $\mathrm{HO}_{2}+\mathrm{NO}$ reaction (R8) is shown in Fig. 7. Nitrate snow chemistry increases ozone formation rates at Summit approximately by a factor of four around noon. The result is an additional 2-3 ppb of $\mathrm{O}_{3}$ in the boundary layer due to snow sourced $\mathrm{NO}_{\mathrm{x}}$ (difference between the base and noNit cases) during the three day model run.

The noBro case shows a smaller difference to the base case. Over the three day model run bromine contributes $1 \mathrm{ppb}$ of boundary layer ozone loss. This small effect can be explained by the very low $\mathrm{BrO}$ mixing ratios at Summit that 


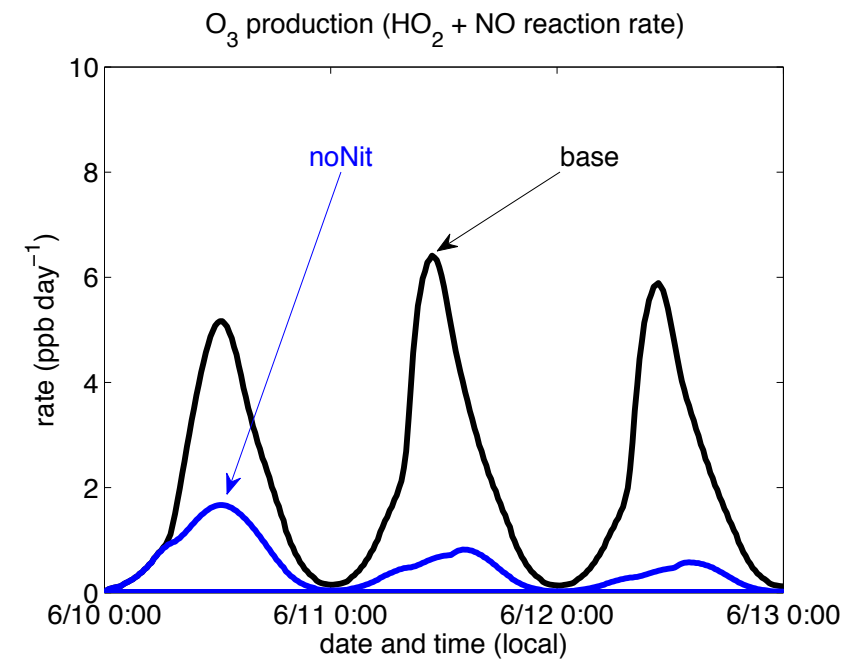

Fig. 7. Ozone production from $\mathrm{NO}$ to $\mathrm{NO}_{2}$ conversion reaction (R8). The average ozone production rate from snow sourced $\mathrm{NO}_{\mathrm{x}}$ results in an additional $2 \mathrm{ppb}$ of $\mathrm{O}_{3}$ in the boundary layer at Summit.

impact ozone formation directly via the destruction of ozone through Reaction (R16) and indirectly via lowering $\mathrm{NO}_{\mathrm{x}}$ levels Reaction (R27). The comparison of the base case with the sensitivity cases shows that snow chemistry has a considerable impact on ozone levels on the Greenland ice sheet, where ozone lifetimes are quite long. Other processes, not involving halogen and nitrogen cycling, clearly also influence ozone levels at Summit.

The model does not predict strong ozone depletion in the snowpack, which has been observed at Summit (Peterson and Honrath, 2001). This is because of the relatively small halogen concentrations in interstitial and because ozone production from $\mathrm{NO}_{\mathrm{x}}$ in the interstitial air offsets most ozone destruction that does occur. Alternatively, the model could under-predict halogen concentrations in interstitial air and the corresponding ozone destruction. It is also possible there is another (currently unknown) mechanism causing ozone destruction in interstitial air. Measurements of halogens and $\mathrm{NO}_{\mathrm{x}}$ in the interstitial air are needed to compare with the model. However, measurements of undisturbed interstitial chemical concentrations are difficult and will likely require developments in measurement techniques.

\subsection{Formaldehyde and hydrogen peroxide snow and boundary layer chemistry}

Formaldehyde (HCHO) is an important precursor of $\mathrm{HO}_{2}$ and a marker for VOC chemistry. It is also known to be released from snow to the atmospheric boundary layer (Hutterli et al., 1999, 2003; Sumner and Shepson, 1999; Dominé and Shepson, 2002; Jacobi et al., 2004; Barret et al., 2011). As there were no HCHO measurements during GSHOX, we compare modeled HCHO mixing ratios with prior measurements at Summit, Greenland (Jacobi et al., 2004). It should be noted, however, that due to differences in environmental conditions, such as snowpack temperature, the comparison should only be considered semi-quantitative. Despite the shortcomings of this comparison the model accurately reflects the HCHO mixing ratios one would expect in the boundary layer at Summit (Fig. 8). The modeled interstitial air $\mathrm{HCHO}$ mixing ratios are about $50-70 \%$ of the noontime values observed by Jacobi et al. (2004), while the nocturnal values again show good agreement.

In the model HCHO is formed through the gas phase Reaction (R9) of $\mathrm{NO}$ with $\mathrm{CH}_{3} \mathrm{O}_{2}$, which results from the oxidation of methane. This reaction occurs in the atmosphere and in the top few centimeters of the snow, where photochemistry is still fast. Organics present in surface snow layers have been proposed to play an important role in HCHO production (Grannas et al., 2004). However, as these processes are largely unknown, our model does not include a sophisticated organic chemistry scheme in the LLL, and relies on a basic $\mathrm{HCHO}$ reaction scheme. It is possible that the discrepancy between the model and observations in the interstitial air at noon can be explained by organic chemistry in the snowpack. In addition, the measurements are likely a lower limit of interstitial air concentrations due to dilution while sampling. In the future, model improvements will be needed to fully represent this chemistry.

For the reactions included in the model (LLL and gas phase photochemistry of $\mathrm{HCHO}$ ) neither chemical production or destruction of $\mathrm{HCHO}$ is as fast as mass transfer processes driven by temperature changes in the snowpack. Increases in $\mathrm{HCHO}$ mixing ratios (Fig. 8) correspond to changes in predicted snowpack temperature published in Thomas et al. (2011). This has been confirmed by recent work focused on physical processes involved in the HCHO air-snow exchanges during OASIS 2009 field campaign at Barrow, Alaska (Barret et al., 2011). In this study, HCHO concentrations in the solid phase were quantitatively explained by solid-state diffusion of $\mathrm{HCHO}$ within snow crystals, without considering the quasi-liquid layer present at the surface of ice crystals, showing that physical processing is essential for predicting $\mathrm{HCHO}$ concentrations.

Michalowski et al. (2000) showed the central role of $\mathrm{HCHO}$ in $\mathrm{HOBr}$ formation during halogen induced ozone depletion events in the coastal Arctic. At Summit where the halogen concentrations are lower, $\mathrm{HOBr}$ formation in the boundary layer is dominated by reaction of $\mathrm{BrO}$ with $\mathrm{HO}_{2}$ (Reaction R14). In the surface snow interstitial air, where $\mathrm{BrO}$ peak concentrations are predicted, at most $3 \%$ of $\mathrm{HOBr}$ formation occurs via reaction with $\mathrm{HCHO}$ (Reaction R17). Unlike the coastal Arctic, the influence of formaldehyde chemistry on bromine activation is much less important at Summit.

Snow sourced hydrogen peroxide, $\mathrm{H}_{2} \mathrm{O}_{2}$, can contribute to the $\mathrm{OH}$ budget and the boundary layer oxidizing capacity over snow upon photolysis. Multiple years of measurements of hydrogen peroxide have been made at Summit, Greenland 

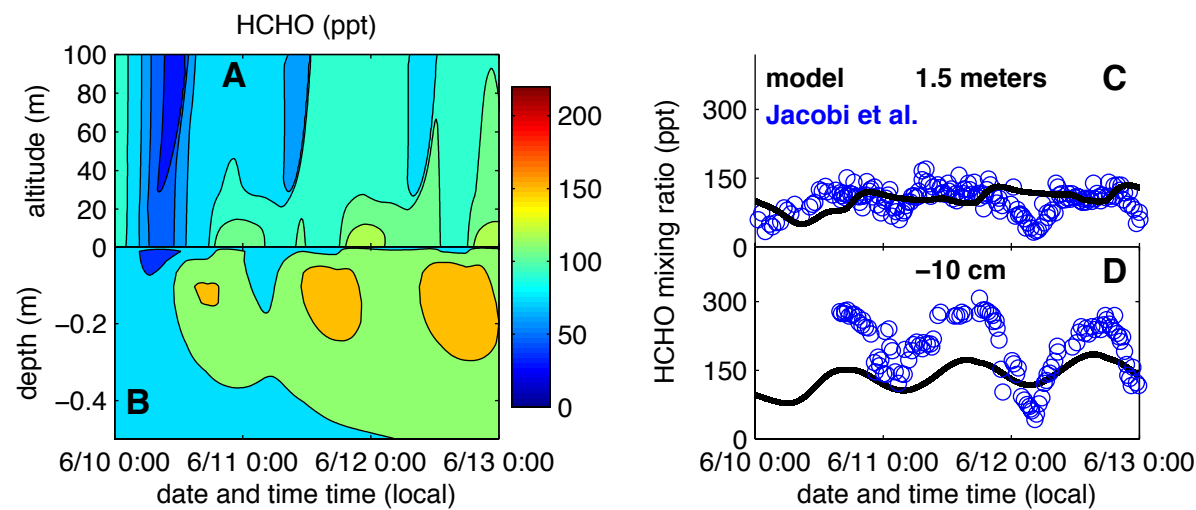

Fig. 8. Model predicted HCHO for the base case. Model results are compared with measurements taken in June 2000 originally published by Jacobi et al. (2004) (c and d). Measurements in the interstitial air during shading experiments have been removed from the comparison.
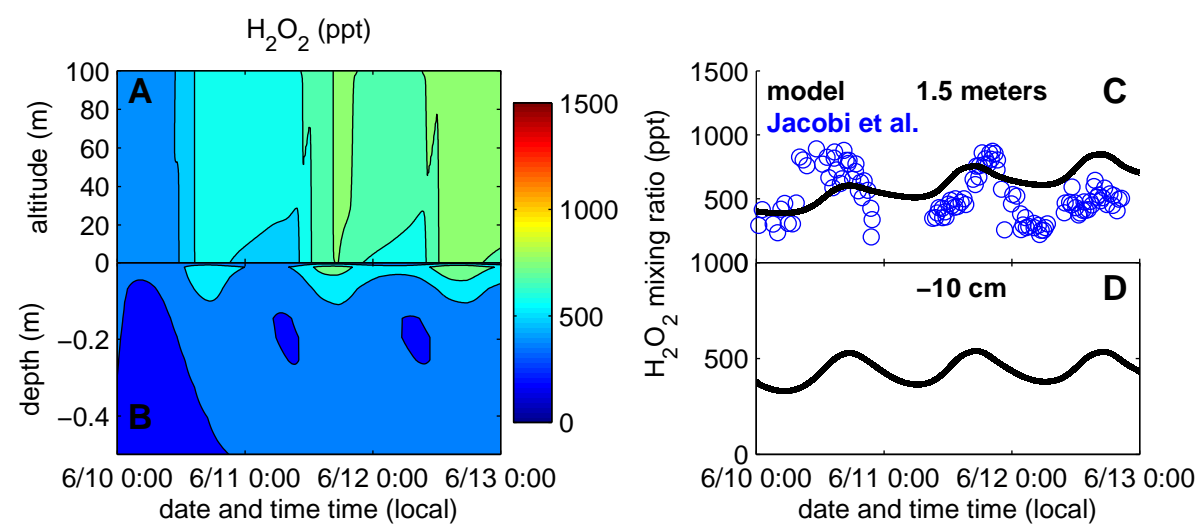

Fig. 9. Model predicted $\mathrm{H}_{2} \mathrm{O}_{2}$ for the base case. Model results are compared with measurements taken in June 2000 originally published by Jacobi et al. (2004) (panel c).

(e.g. Hutterli et al., 2001). As no $\mathrm{H}_{2} \mathrm{O}_{2}$ measurements were made during GSHOX we also compare $\mathrm{H}_{2} \mathrm{O}_{2}$ modeled in the base case with prior measurements during summer 2000 (Jacobi et al., 2004) (Fig. 9). $\mathrm{H}_{2} \mathrm{O}_{2}$ shows similar diurnal patterns as $\mathrm{HCHO}$, with higher mixing ratios at noon. The modeled mixing ratios reproduce the observed $\mathrm{H}_{2} \mathrm{O}_{2}$ within a factor of two, but the model does not correctly capture the amplitude of the diurnal variation. However, this comparison is subject to the same shortcomings as discussed above for $\mathrm{HCHO}$. Measured $\mathrm{H}_{2} \mathrm{O}_{2}$ fluxes in June 1996 suggested a daytime $\mathrm{H}_{2} \mathrm{O}_{2}$ release from the surface snow and redeposition at night (Hutterli et al., 2001). However, shading experiments did not impact $\mathrm{H}_{2} \mathrm{O}_{2}$ concentrations in the firn air, therefore the $\mathrm{H}_{2} \mathrm{O}_{2}$ is most likely not photochemically produced in the snowpack (Jacobi et al., 2004).

During other years, higher $\mathrm{H}_{2} \mathrm{O}_{2}$ and $\mathrm{HCHO}$ levels have been measured at Summit. Frey et al. (2009) presented $\mathrm{H}_{2} \mathrm{O}_{2}$ measurements at Summit from 2003 and 2004 which ranged from $1.4 \mathrm{ppbv}$ in June/July to $100-300 \mathrm{pptv}$ in March-early May. Summer $2000 \mathrm{H}_{2} \mathrm{O}_{2}$ levels were lower, as shown by Jacobi et al. (2004), suggesting both seasonal and inter-annual variability in radical sources may be important. But, given that $\mathrm{H}_{2} \mathrm{O}_{2}$ and $\mathrm{HCHO}$ were not measured during GSHOX the comparison with prior years can only be considered qualitative. To investigate the impact of higher primary $\mathrm{OH}$ sources on $\mathrm{OH}$ levels, we have completed a model sensitivity run with additional peroxide and formaldehyde (1.4 ppbv and 230 pptv respectively). These model results have been compiled and presented in the Supplement. This sensitivity study shows that a significant increase in these radical precursors only has a small impact on mid-day $\mathrm{OH}$ concentrations during the first day of the model run (a $3 \%$ increase). The lack of sensitivity of $\mathrm{OH}$ levels to additional hydrogen peroxide is not surprising, given that $\mathrm{OH}$ concentrations are well buffered and largely determined by recycling reactions, for example Reaction (R8).

In the base case, most of the $\mathrm{H}_{2} \mathrm{O}_{2}$ results from the gas phase self reaction of $\mathrm{HO}_{2}$ in the boundary layer, rather than release of peroxide from the surface snow. While the LLL chemistry in our model may be oversimplified to correctly predict the flux of hydrogen peroxide out of the snowpack, 


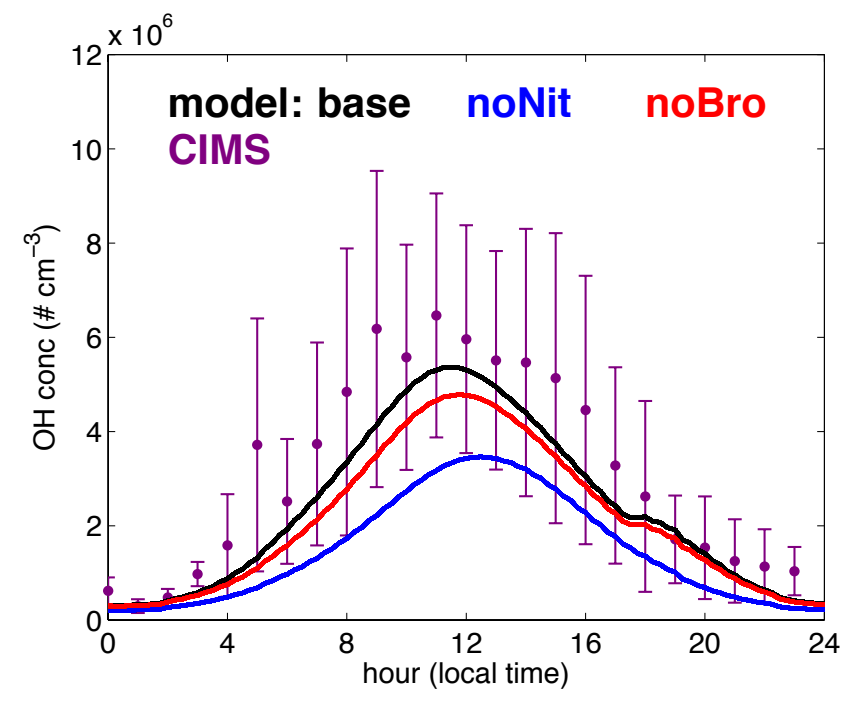

Fig. 10. Model predicted $\mathrm{OH}$ concentrations for the second day of the three day model run for the base, noNit, and noBro cases compared to hourly averaged $\mathrm{OH}$ concentrations for the time periods classified as influenced by local air. The error bars on the $\mathrm{OH}$ measurements indicate the standard deviation upon hourly averaging. The base case model predicted $\mathrm{OH}$ is below mean values of the measurements, but well within the error bars. Without bromine chemistry, $\mathrm{OH}$ is predicted to be lower than the base case. Without snow sourced $\mathrm{NO}_{\mathrm{x}}$ chemistry, the $\mathrm{OH}$ concentrations are predicted to be much lower than the measured values.

gas phase chemistry in the boundary layer can largely explain the $\mathrm{H}_{2} \mathrm{O}_{2}$ levels measured during summer 2000 .

\section{4 $\mathrm{HO}_{\mathrm{x}}$ chemistry of the boundary layer}

The previous sections showed that snow photochemistry influences many species that directly or indirectly impact $\mathrm{OH}$, $\mathrm{HO}_{2}$, and $\mathrm{RO}_{2}$ radical concentrations. In this section we compare the modeled and measured $\mathrm{OH}$ and $\mathrm{HO}_{2}+\mathrm{RO}_{2}$ in order to quantify the impact of snow chemistry on boundary layer oxidation capacity, which for the purposes of this study we define as the sum of $\mathrm{OH}, \mathrm{HO}_{2}$, and $\mathrm{RO}_{2}$. Before analyzing the details of this chemistry we will first compare the model results with observations of $\mathrm{OH}$ and $\mathrm{HO}_{2}+\mathrm{RO}_{2}$ during GSHOX to ensure that the model accurately describes this chemistry. As in the case of $\mathrm{NO}$ and $\mathrm{BrO}$ we will solely concentrate on time periods during which FLEXPART predicts air measured at Summit is influenced by snowpack emissions for at least 3 days (see details of these local air events in Stutz et al., 2011). We then calculate hourly averaged $\mathrm{OH}$ and $\mathrm{HO}_{2}+\mathrm{RO}_{2}$ mixing ratios using the local air periods between 9-14 June 2008 and 23-26 June 2008 for the purpose of comparison with model results. Hourly averaging reduces the statistical error of the measurements and also removes day-to-day variability in the data. The averaged data together with the standard deviation from the hourly averaging (error bars) are shown in Figs. 10 and 11. As reported by

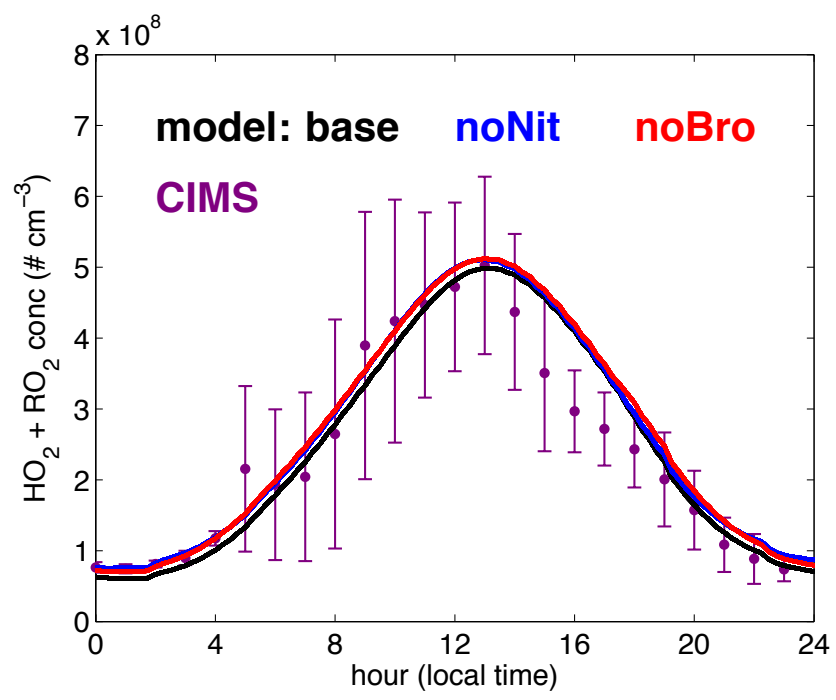

Fig. 11. Model predicted $\mathrm{HO}_{2}+\mathrm{RO}_{2}$ (where $\mathrm{RO}_{2}$ represents the sum of all organic peroxyl radicals for both the measurement and the model) concentrations for the second day of a three day model run for the base, noNit, and noBro cases compared to hourly averaged $\mathrm{HO}_{2}+\mathrm{RO}_{2}$ concentrations for the time periods classified as influenced by local air. The error bars on the $\mathrm{HO}_{2}+\mathrm{RO}_{2}$ measurements indicates the standard deviation upon hourly averaging.

Liao et al. (2011) the systematic uncertainties due to the calibration of the CIMS for $\mathrm{OH}$ is $\sim 30 \%$ and that for $\mathrm{HO}_{2}+\mathrm{RO}_{2}$ is $\sim 35 \%$. We can thus consider the error bars as a good measure of the observational uncertainty.

We compare model results at a height of $1.5 \mathrm{~m}$ with surface measurements made at a similar height above the snow surface. The observations show a diurnal profile with a clear maximum of $6 \times 10^{6}$ molecules $\mathrm{cm}^{-3}$ around noon and values of $0.5-1 \times 10^{6}$ molecules $\mathrm{cm}^{-3}$ at night. The base case model run including both nitrogen and bromine snow chemistry shows excellent agreement with the observations within the uncertainties. The model seems to under predict the average peak $\mathrm{OH}$ concentrations by $\sim 10 \%$, which is much less than the systematic uncertainty in the $\mathrm{OH}$ measurement. The model $\mathrm{OH}$ follows the observed diurnal behavior well. It also shows a secondary peak around 18:00 LT that forms due to the onset of a stable inversion that traps $\mathrm{NO}_{\mathrm{x}}$ and reactive bromine emissions in a shallow layer near the surface. It is difficult to clearly distinguish this effect in the measurements, but the observed $\mathrm{OH}$ in the hours before midnight is higher than in the early hours of the morning, as predicted by the model.

The CIMS technique is sensitive to both the hydroperoxyl radical and organic peroxy radicals $\left(\mathrm{HO}_{2}+\mathrm{RO}_{2}\right)$ (Liao et al., 2011), we therefore sum $\mathrm{HO}_{2}+\mathrm{RO}_{2}$ species in the model for comparison (Fig. 11). The base case model correctly predicts the total mid-day peroxy radical concentration of $5 \times 10^{8}$ molecules $\mathrm{cm}^{-3}$, and nighttime values of $0.7 \times 10^{8}$ molecules $\mathrm{cm}^{-3}$. The data and the model show a 

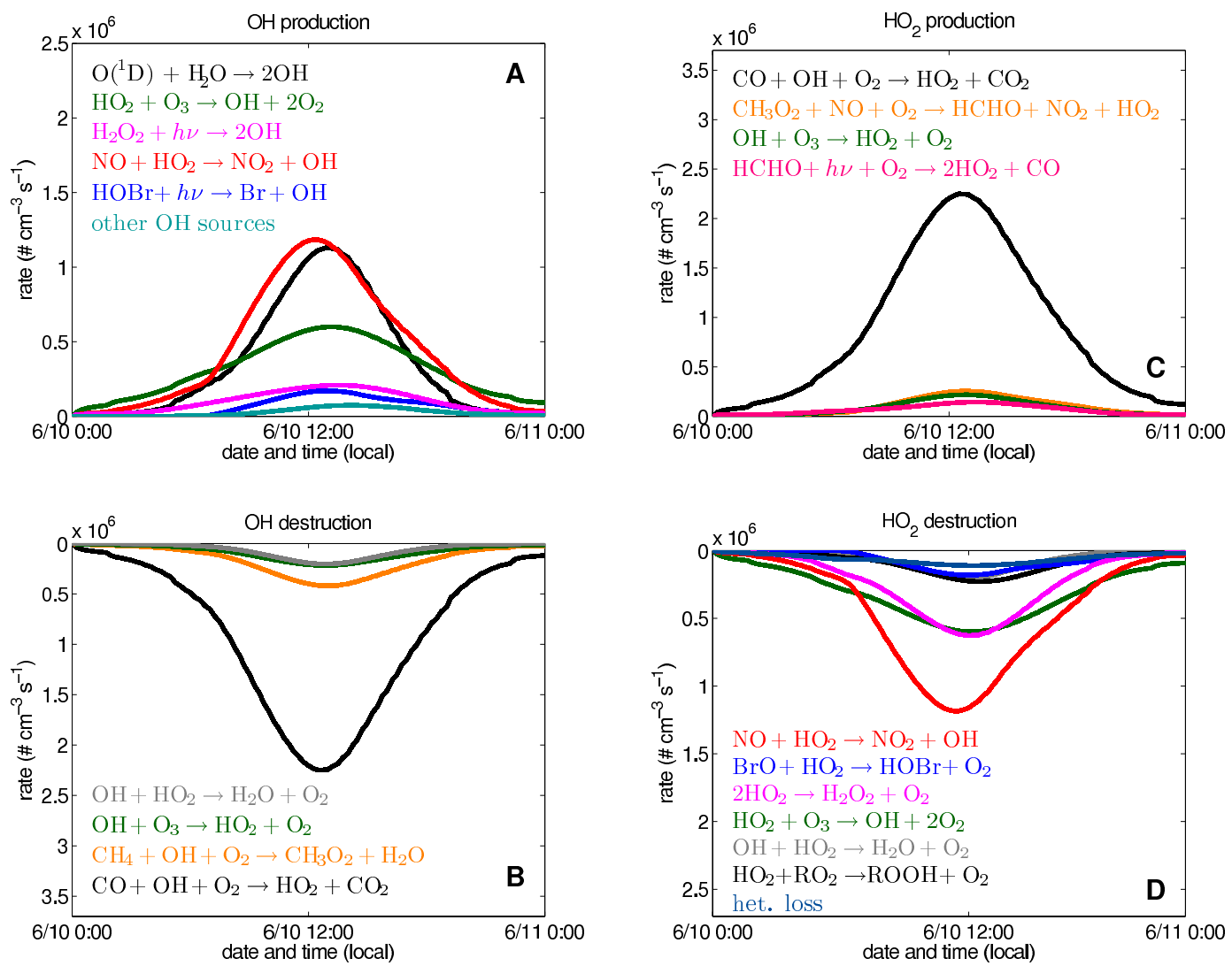

Fig. 12. $\mathrm{OH}$ and $\mathrm{HO}_{2}$ production and destruction reaction rates in panels (a-d), including primary production, $\mathrm{HO}_{2}$ to $\mathrm{OH}$ cycling reactions, and terminal loss processes on June 10, 2008.

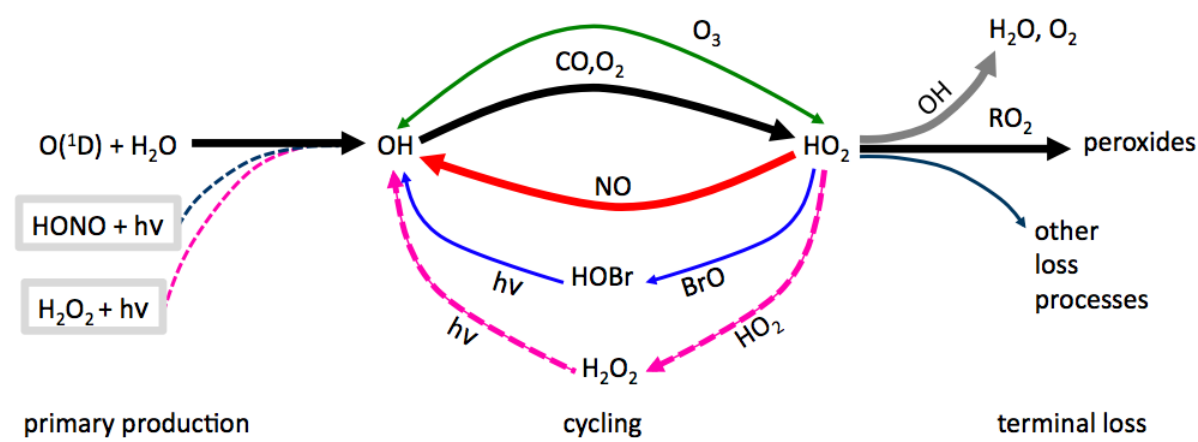

Fig. 13. Scheme of the major $\mathrm{OH}$ sources, $\mathrm{HO}_{\mathrm{x}}$ interconversion reactions, and $\mathrm{HO}_{2}$ loss processes shown in Fig. 12. The large arrows indicate the most important processes in the model at Summit during the focus period. The gray boxes indicate primary $\mathrm{OH}$ sources that may be due to snow emissions. $\mathrm{H}_{2} \mathrm{O}_{2}$ may contribute more to $\mathrm{OH}$ levels, as indicated by the dashed magenta line.

similar nocturnal asymmetry as $\mathrm{OH}$, caused by the onset of the nocturnal inversion.

The successful comparison of the field observations with the model results for $\mathrm{OH}$ and $\mathrm{HO}_{2}+\mathrm{RO}_{2}$ gives confidence that the model correctly describes the atmospheric radical chemistry over snow at Summit. We note that this is the first unconstrained model calculation (only the surface temperatures were constrained and the LLL partitioning of nonvolatile species was adjusted at the beginning of the run) that correctly represents $\mathrm{HO}_{\mathrm{x}}$ chemistry and the oxidation capacity of the boundary layer over snow.

To demonstrate the effect of bromine and nitrogen chemistry on $\mathrm{HO}_{\mathrm{x}}$ levels and the oxidation capacity of the boundary layer we compare the predicted $\mathrm{OH}$ concentrations for two sensitivity runs (noBro and noNit) to the base case model run in Fig. 10. There is almost a factor of 2 more $\mathrm{OH}$ due to emissions of $\mathrm{NO}_{\mathrm{x}}$ to the boundary layer, depending on time of day. Similarly, gas phase bromine impacts boundary layer 


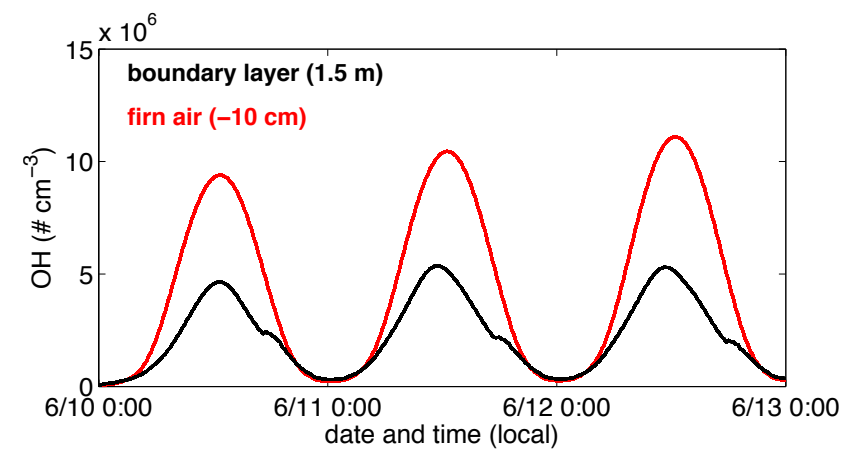

Fig. 14. OH concentrations predicted in the atmosphere and interstitial air for the base case. The model predicts a significantly enhanced oxidizing environment in the interstitial air.

$\mathrm{OH}$ concentrations, but less so than snow sourced $\mathrm{NO}_{\mathrm{x}}$. The sensitivity run shows there is between 6-20\% increase in $\mathrm{OH}$ upon including snow bromine chemistry, which is similar to the numbers predicted by Stutz et al. (2011). On the other hand snow sourced $\mathrm{NO}_{\mathrm{x}}$ and halogens do not significantly impact the total peroxy radical concentration, shown by the sensitivity runs in Fig. 11.

In order to understand these results and $\mathrm{HO}_{\mathrm{x}}$ cycling over snow in general, the $\mathrm{OH}$ production and $\mathrm{HO}_{2}$ loss reactions were extracted from the model (Fig. 12). The most important primary $\mathrm{OH}$ source is $\mathrm{O}\left({ }^{1} \mathrm{D}\right)+\mathrm{H}_{2} \mathrm{O}$ (Reaction R2) (Fig. 12a). Hydrogen peroxide photolysis (Reaction R4) also contributes to $\mathrm{OH}$, only a small portion of this is a primary $\mathrm{OH}$ source (from snow emissions of $\mathrm{H}_{2} \mathrm{O}_{2}$ ). However, the sensitivity run presented in the Supplement shows that for a case with higher hydrogen peroxide concentrations the contribution of $\mathrm{H}_{2} \mathrm{O}_{2}$ to primary $\mathrm{OH}$ is consistent with the study of Chen et al. (2007). These higher concentrations likely result from snowpack emissions of hydrogen peroxide. In the model the majority of $\mathrm{H}_{2} \mathrm{O}_{2}$ is formed in the gas phase via the $\mathrm{HO}_{2}$ self reaction, and therefore constitutes $\mathrm{HO}_{2}$ recycling back to $\mathrm{OH}$. $\mathrm{HONO}$ is a minor source of $\mathrm{OH}$ in the boundary layer (included in other $\mathrm{OH}$ sources) because it rapidly photolyzes in snow (see Sect. 4.1) before reaching the boundary layer. Of the $\mathrm{HO}_{\mathrm{x}}$ recycling reactions that convert $\mathrm{HO}_{2}$ back to $\mathrm{OH}$, the reaction of $\mathrm{NO}$ with $\mathrm{HO}_{2}$ (Reaction $\mathrm{R} 8$ ) dominates. It should be noted that the rate of this reaction determines the chemical ozone formation rate at Summit, as discussed in Sect. 4.2. Bromine chemistry constitutes a small contribution to the $\mathrm{OH}$ in the boundary layer at Summit (via $\mathrm{HOBr}$ photolysis, Reaction R15), compared to recycling via the reaction of $\mathrm{NO}$ with $\mathrm{HO}_{2}$. The second most important $\mathrm{OH}$ formation reaction is the one between $\mathrm{HO}_{2}$ and ozone. In contrast to the other $\mathrm{OH}$ formation mechanisms this reaction continues to recycle $\mathrm{HO}_{2}$ back to $\mathrm{OH}$ at night, and is responsible for much of the nocturnal $\mathrm{OH}$ found at Summit. The reaction also constitutes an important chemical ozone loss mechanism in the model. In addition, it balances a portion of the ozone formation that follows from the $\mathrm{NO}+\mathrm{HO}_{2}$ reaction. Another chemical ozone loss shown in Fig. 12 is the $\mathrm{O}\left({ }^{1} \mathrm{D}\right)+\mathrm{H}_{2} \mathrm{O}$ reaction (R2). The third, more indirect, ozone loss reaction is the photolysis of $\mathrm{HOBr}$, which is formed through the reaction of $\mathrm{HO}_{2}$ and $\mathrm{BrO}$ (Reaction R14). This constitutes ozone destruction because one of the photolysis products for $\mathrm{HOBr}$ is the bromine radical, $\mathrm{Br}$, which acts to destroy ozone (Reaction R16). The bromine reaction cycle through $\mathrm{HOBr}$ is somewhat less efficient in destroying ozone than the other two pathways, but nevertheless adds considerably to the ozone loss at Summit. Together the three reaction pathways destroy ozone at a higher rate than it is produced through the $\mathrm{NO}+\mathrm{HO}_{2}$ reaction (Reaction $\mathrm{R} 8$ ), explaining, together with the surface deposition of ozone, the slow ozone decrease in Fig. 6.

$\mathrm{OH}$ loss processes at Summit include reactions with $\mathrm{CO}$ (most important), methane, ozone, and $\mathrm{HO}_{2}$ (Fig. 12b). Another $\mathrm{OH}$ loss reaction is $\mathrm{OH}+\mathrm{NO}_{2}$ to form nitric acid, however the channel is a minor $\mathrm{OH}$ loss process (not shown in the figure). The reaction of $\mathrm{OH}$ with $\mathrm{CO}$ (Reaction $\mathrm{R} 6$ ) is also the main sources of $\mathrm{HO}_{2}$ in the model (Fig. 12c). As expected, $\mathrm{OH}+\mathrm{CH}_{4}$ is the main source of $\mathrm{RO}_{2}$.

The main recycling pathways for $\mathrm{HO}_{\mathrm{x}}$, which we discussed as $\mathrm{OH}$ sources above, are also some of the most important $\mathrm{HO}_{2}$ loss mechanisms (Fig. 12d). Formation of organic peroxides from reaction of $\mathrm{HO}_{2}$ with $\mathrm{RO}_{2}$, the reaction of $\mathrm{HO}_{2}$ with $\mathrm{OH}$, and $\mathrm{HO}_{2}$ loss to aerosol are the most important terminal loss process for $\mathrm{HO}_{\mathrm{x}}$. Together with the $\mathrm{OH}$ $+\mathrm{NO}_{2}$ reaction and reaction of $\mathrm{HO}_{2}$ with $\mathrm{NO}_{2}$ they balance the primary $\mathrm{OH}$ formation pathways. All the loss processes show the expected diurnal cycle, with photochemistry fastest at solar noon, that is also found in the $\mathrm{HO}_{2}$ sources. The most important production, cycling, and loss processes for $\mathrm{HO}$ are summarized in Fig. 13.

Using this analysis and the results from our sensitivity study one can now understand how snow photochemistry influences $\mathrm{OH}$ levels and the atmospheric oxidation chemistry. As illustrated in Figs. 12 and 13 the emission of $\mathrm{NO}_{\mathrm{x}}$ and bromine impact $\mathrm{OH}$ recycling reactions. In the absence of snow sourced $\mathrm{NO}_{\mathrm{x}}$ the levels of $\mathrm{NO}$ would be significantly reduced (Fig. 3) and the cycling of $\mathrm{HO}_{\mathrm{x}}$ through the $\mathrm{NO}+\mathrm{HO}_{2}$ channel have a corresponding reduction, with the net effect leading to $50 \%$ lower $\mathrm{OH}$ concentrations as shown in Fig. 10. At the same time, reduced $\mathrm{NO}_{\mathrm{x}}$ also slows the rate of ozone formation. It is clear from Fig. 10 that the $\mathrm{OH}$ budget at Summit cannot be closed without including snow photochemistry.

Similarly the absence of snow bromine chemistry decreases $\mathrm{OH}$ because the formation channel through $\mathrm{HOBr}$ photolysis is missing. However, the effect on ozone is negative as the $\mathrm{HOBr}$ cycle leads at the same time to ozone destruction. The absence of snow sourced bromine has a less important contribution to improving the comparison for $\mathrm{OH}$ between model and observations (Fig. 10). 
Hutterli et al. (2001) suggested that $\mathrm{H}_{2} \mathrm{O}_{2}$ released from surface snow increased the average boundary layer $\mathrm{H}_{2} \mathrm{O}_{2}$ concentrations $(\times 7)$ and increased the boundary layer $\mathrm{OH}$ concentrations by $70 \%$ and the $\mathrm{HO}_{2}$ concentrations by $50 \%$. If the predicted $\mathrm{H}_{2} \mathrm{O}_{2}$ concentrations are correct, hydrogen peroxide contributed less significantly to $\mathrm{OH}$ production in the boundary layer during 2008. In addition, in the model $\mathrm{H}_{2} \mathrm{O}_{2}$ has a more important impact on $\mathrm{OH}$ through gas phase recycling of $\mathrm{HO}_{2}$ to $\mathrm{OH}$, rather than snowpack emissions of $\mathrm{H}_{2} \mathrm{O}_{2}$. HCHO photolysis to form $\mathrm{HO}_{2}$ is a minor source of $\mathrm{HO}_{\mathrm{x}}$ in the model (Fig. 12c). Together, in our model, snow emissions of $\mathrm{HCHO}$ and $\mathrm{H}_{2} \mathrm{O}_{2}$ have a minor impact on $\mathrm{HO}_{x}$ cycling in the boundary layer. There are shortcomings in our model representation of their chemistry, but the model predicted levels of these species is in line with prior measurements.

While the total air volume in the snow is much smaller than that of the overlying boundary layer, gas phase chemical processing of atmospheric species in the snow can impact atmospheric composition through the air exchanged between the boundary layer and snow. Little is known about the radical chemistry in interstitial air due to the inherent difficulty to sample interstitial air without at the same time sampling atmospheric air, and the necessity to use in-snow inlets and sampling lines. In an initial study, Beyersdorf et al. (2007) showed using hydrocarbon gas ratios in a transparent snow chamber with undisturbed surface snow that the lower limit to peak $\mathrm{OH}$ radical concentration on 10-12 July 2003 was $3.0 \times 10^{6} \mathrm{~cm}^{-3}$. It is useful to employ a coupled snowatmosphere model to study the oxidizing environment of the interstitial air, which has implications for chemistry occurring in the snowpack (e.g. processing of mercury and persistent organic pollutants transported to the Arctic). We show in Fig. 14 that the environment of the interstitial air $(10 \mathrm{~cm}$ depth) is predicted to be significantly more oxidizing than the boundary layer, with mid-day $\mathrm{OH}$ concentrations in the firn air approximately 2 times greater than in the boundary layer. There are several potential explanations for the discrepancy between Beyersdorf et al. (2007) and the present study. It's possible that the model over predicts $\mathrm{NO}_{\mathrm{x}}$ concentrations present in interstitial air, therefore over predicting $\mathrm{OH}$. In addition, it's possible that during sampling Beyersdorf et al. (2007) measured hydrocarbons from deeper in firn air, which would contain lower $\mathrm{OH}$ concentrations. Clearly, further investigation of the oxidizing environment in the interstitial air within the surface snowpack is needed.

We have shown that snow chemistry increases the amount of $\mathrm{OH}$ in the boundary layer, while leaving $\mathrm{HO}_{2}+\mathrm{RO}_{2}$ unchanged. Faster recycling of $\mathrm{HO}_{2}$ back to $\mathrm{OH}$ increases the steady state $\mathrm{OH}$ concentration compared to the halogen free atmosphere. Similarly, increased $\mathrm{NO}_{\mathrm{x}}$ also contributes to faster recycling of $\mathrm{HO}_{2}$ to $\mathrm{OH}$. Together, snow sourced halogen and nitrogen chemistry in the boundary layer doubles the predicted mid-day $\mathrm{OH}$ concentration.

\section{Summary and conclusions}

We have presented results using a coupled air-snow chemistry model of radical chemistry over snow in the remote high Arctic. The modeled boundary layer concentrations of $\mathrm{OH}$ and $\mathrm{HO}_{2}+\mathrm{RO}_{2}$ show excellent agreement with measurements performed during periods influenced by local air during the 2008 GSHOX experiment. Together with the previously reported agreement of the modeled $\mathrm{NO}$ and $\mathrm{BrO}$ mixing ratios with observations during these periods (Thomas et al., 2011), we conclude that the model represents accurately the influence of the snowpack on boundary layer chemistry during GSHOX. It should also be noted that the model correctly reproduces measurements, despite the assumptions made in representation of the LLL thickness, ion content, and chemistry, The current version of the model also contains a simplified representation of snowpack physics, which is a complex process that depends on temperature (e.g. Dominé et al., 2008). In the future, work towards a more complete description of snowpack physics and chemistry in one model is needed to create a model that accurately predicts the coupling between snow chemistry and physics with the overlying atmosphere.

We used the model to investigate how chemistry in the snow-pack influences the oxidation capacity and ozone levels in boundary layer air, using sensitivity runs and a detailed analysis of the $\mathrm{HO}_{\mathrm{x}}$ reaction rates. The following general conclusions can been derived from our study:

- The major impact of snow chemistry on $\mathrm{OH}$ is due to the chemical formation of $\mathrm{NO}_{\mathrm{x}}$ through the photolysis of nitrate, followed by the transfer of $\mathrm{NO}_{\mathrm{x}}$ from the snowpack into the atmosphere. The snow $\mathrm{NO}_{\mathrm{x}}$ sources leads to a near doubling of the predicted $\mathrm{OH}$ via reaction of $\mathrm{NO}$ with $\mathrm{HO}_{2}$, and thus a shift in the $\mathrm{OH}: \mathrm{HO}_{2}$ ratio towards $\mathrm{OH}$. Under the investigated conditions, bromine has a less important impact, increasing $\mathrm{OH}$ levels by 6-20\%, also shifting the $\mathrm{OH}: \mathrm{HO}_{2}$ ratio towards $\mathrm{OH}$. Together, snow emissions of $\mathrm{NO}_{\mathrm{x}}$ and bromine double model predicted $\mathrm{OH}$, increasing boundary layer oxidation capacity.

- Boundary layer ozone is impacted by both halogen and $\mathrm{NO}_{\mathrm{x}}$ emissions from the surface snow. Nitrogen cycling contributes an additional $2 \mathrm{ppb}$ of ozone in the boundary layer over the three day model run. Bromine emissions from the surface snow destroy $1 \mathrm{ppb}$ of ozone over three days. In effect, the snowpack emissions offset would result in net ozone production, but other processes contribute and result in a slight ozone decrease (measured and modeled) during the focus period.

- Halogen and nitrogen cycling are connected via LLL reactions as well as gas phase reactions, therefore the ratio of bromide to nitrate in surface snow impacts the amount of reactive species released from the 
snowpack, and thus indirectly the $\mathrm{OH}$ levels and the atmospheric oxidation capacity. Formation of bromine nitrate $\left(\mathrm{BrNO}_{3}\right)$ in the gas phase results in higher bromine concentrations without nitrate chemistry in the snowpack. Without bromine in the liquid layer, $\mathrm{NO}_{2}$ formation in the LLL is reduced and results in lower predicted $\mathrm{NO}_{\mathrm{x}}$ fluxes. However, increased nitrite concentrations in the liquid layer without bromide resulted in increased HONO release from the snowpack.

- A comparison of predicted and measured HONO (mistchamber soluble nitrite) shows that the model over predicts interstitial air HONO, but under predicts boundary layer HONO. Under no conditions are we able to predict $10 \mathrm{ppt}$ of boundary layer HONO due to its rapid photolysis at the surface, which is in good agreement with measured photolysis rates at Summit. There is evidence for a large missing boundary layer HONO or soluble nitrite source that is yet to be identified. Given the agreement between the model and measurements for both $\mathrm{OH}$ and $\mathrm{NO}$, any additional HONO source would have to be identified along with sinks for the additional $\mathrm{OH}$ and $\mathrm{NO}$ resulting from HONO photolysis. It is also possible there is another source of soluble nitrite in addition to HONO.

- Model predicted $\mathrm{HCHO}$ and $\mathrm{H}_{2} \mathrm{O}_{2}$ are in agreement with prior measurements taken in summer 2000 at Summit. However, measurements in summer 2000 were lower than other campaign periods (Hutterli et al., 2001; Frey et al., 2009). Temperature cycling dominates predicted HCHO in the model. HCHO plays a less important role in bromine recycling at Summit than in the coastal Arctic. Gas phase formation of $\mathrm{H}_{2} \mathrm{O}_{2}$ in the boundary layer from the $\mathrm{HO}_{2}$ self reaction sustains boundary layer $\mathrm{H}_{2} \mathrm{O}_{2}$ concentrations. The impact of $\mathrm{H}_{2} \mathrm{O}_{2}$ on boundary layer $\mathrm{OH}$ concentrations is primarily via recycling of $\mathrm{HO}_{2}$ back to $\mathrm{OH}$, with limited impact of snowpacks emissions. However, this model was not developed specifically to study $\mathrm{H}_{2} \mathrm{O}_{2}$ or $\mathrm{HCHO}$, therefore the chemical scheme may be inadequate to correctly predict LLL concentrations. Model predicted $\mathrm{H}_{2} \mathrm{O}_{2}$ and $\mathrm{HCHO}$ mixing ratios are adequate for the purposes of capturing their influence on oxidation capacity, but their LLL chemistry and cycling (including solid diffusion) will need to be investigated further in the future.

While these conclusions were derived for a specific case of Summit, Greenland, the identifed mechanisms may also be active at other snow covered locations. Additional modeling studies, backed up by field observations as well as new laboratory studies, are needed to confirm that our results are representative for other snow covered locations. This in-depth research is needed to provide complete understanding, which can be used to develop predictive modeling capabilities and parameterizations of these processes for inclusion in regional and global atmospheric chemistry models. Despite the simplified parameterization of processes, such as LLL physics and chemistry, air transport in and out of snow, etc., our study shows that photochemical processing in snow is essential to accurately describe the mechanisms controlling boundary layer ozone chemistry and oxidation capacity.

\section{Supplementary material related to this article is available online at: http://www.atmos-chem-phys.net/12/ 6537/2012/acp-12-6537-2012-supplement.pdf.}

Acknowledgements. The authors acknowledge H.-W. Jacobi, J. Burkhart, D. Helmig, B. Seok, R. Honrath, Z. Courville, C. Anastasio, and P. Shepson for helpful discussions. The authors would like to thank all the members of the GSHOX campaign and the NSF GEO ATM Tropospheric Chemistry program for funding (Grant ATM-0612279:002). Logistic support was provided by the NSF OPP Arctic Research Support and Logistics program and $\mathrm{CH} 2 \mathrm{MHill}$ Polar Services. In addition, we extend thanks to the New York Air National Guard for the heavy airlift as well as thanks for permission to conduct research at Summit granted by the Danish Polar Center and Greenland Home Rule.

Edited by: J. Abbatt

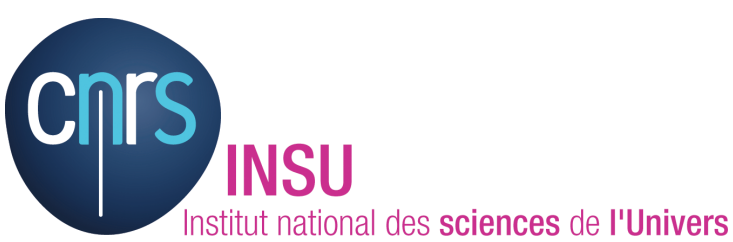

The publication of this article is financed by CNRS-INSU.

\section{References}

Abbatt, J. P. D., Thomas, J. L., Abrahamsson, K., Boxe, C., Granfors, A., Jones, A. E., King, M. D., Saiz-Lopez, A., Shepson, P. B., Sodeau, J., Toohey, D. W., Toubin, C., von Glasow, R., Wren, S. N., and Yang, X.: Halogen activation via interactions with environmental ice and snow in the polar lower troposphere and other regions, Atmos. Chem. Phys., 12, 6237-6271, doi:10.5194/acp-12-6237-2012, 2012.

Anastasio, C. and Chu, L.: Photochemistry of Nitrous Acid (HONO) and Nitrous Acidium Ion $\left(\mathrm{H}_{2} \mathrm{ONO}^{+}\right)$in Aqueous Solution and Ice, Environ. Sci. Technol., 43, 1108-1114, doi:10.1021/es802579a, 2009.

Anderson, P. S. and Neff, W. D.: Boundary layer physics over snow and ice, Atmos. Chem. Phys., 8, 3563-3582, doi:10.5194/acp-83563-2008, 2008.

Barret, M., Dominé, F., Houdier, S., Gallet, J.-C., Weibring, P., Walega, J., Frieß, A., and Richter, D.: Formaldehyde in the Alaskan Arctic snowpack: Partitioning and physical processes involved in air-snow exchanges, J. Geophys. Res., 116, D00R03, doi:10.1029/2011JD016038, 2011. 
Bartels-Rausch, T. and Donaldson, D. J.: $\mathrm{HONO}$ and $\mathrm{NO}_{2}$ evolution from irradiated nitrate-doped ice and frozen nitrate solutions, Atmos. Chem. Phys. Discuss., 6, 10713-10731, doi:10.5194/acpd6-10713-2006, 2006.

Beine, H., Colussi, A. J., Amoroso, A., Esposito, G., Montagnoli, M., and Hoffmann, M. R.: HONO emissions from snow surfaces, Environ. Res. Lett., 3, 045005, doi:10.1088/17489326/3/4/045005, 2008.

Beyersdorf, A. J., Blake, N. J., Swanson, A. L., Meinardi, S., Dibb, J. E., Sjostedt, S., Huey, G., Lefer, B., Rowland, F. S., Blake, D. R.: Hydroxyl concentration estimates in the sunlit snowpack at Summit, Greenland, Atmos. Environ., 41, 5101-5109, 10.1016/j.atmosenv.2006.08.058, 2007.

Chameides, W. L.: The Photochemistry of a Remote Marine Stratiform Cloud, J. Geophys. Res., 89, 4739-4755, 1984.

Chen, G., Huey, L. G., Crawford, J. H., Olson, J. R., Hutterli, M. A., Sjostedt, S., Tanner, D., Dibb, J., Lefer, B., Blake, N., Davis, D., and Stohl, A.: An assessment of the polar $\mathrm{HO}_{\mathrm{x}}$ photochemical budget based on 2003 Summit Greenland field observations, Atmos. Environ., 41, 7806-7820, doi:10.1016/j.atmosenv.2007.06.014, 2007.

Crawford, J. H., Davis, D. D., Chen, G., Buhr, M., Oltmans, S., Weller, R., Mauldin, L., Eisele, F., Shetter, R., Lefer, B., Arimoto, R., and Hogan, A.: Evidence for photochemical production of ozone at the South Pole surface, Geophys. Res. Lett., 28, 36413644, doi:10.1029/2001GL013055, 2001.

Cunningham, J. and Waddington, E. D.: Snow physics as Air flow and dry deposition of non-sea salt sulfate in polar firn: paleoclimatic implications, Atmos. Environ., 27A, 2943-2956, 1993.

Davis, D., Nowak, J. B., Chen, G., Buhr, M., Arimoto, R., Hogan, A., Eisele, F., Mauldin, L., Tanner, D., Shetter, R., Lefer, B., and McMurry, P.: Unexpected High Levels of NO Observed at South Pole, Geophys. Res. Lett., 28, 3625-3628, doi:10.1029/2000GL012584, 2001.

Dibb, J., Arsenault, M., Peterson, M., and Honrath, R.: Fast nitrogen oxide photochemistry in Summit, Greenland snow, Atmos. Environ., 36, 2501-2511, doi:10.1016/S1352-2310(02)00130-9, 2002.

Dibb, J. E., Ziemba, L. D., Luxford, J., and Beckman, P.: Bromide and other ions in the snow, firn air, and atmospheric boundary layer at Summit during GSHOX, Atmos. Chem. Phys., 10, 99319942, doi:10.5194/acp-10-9931-2010, 2010.

Dominé, F. and Shepson, P. B.: Air-Snow Interactions and Atmospheric Chemistry, Science, 297, 1506-1510, doi:10.1126/science.1074610, 2002.

Dominé, F., Albert, M., Huthwelker, T., Jacobi, H. W., Kokhanovsky, A., Lehning, M., Picard, G., and Simpson, W. R.: Snow physics as relevant to snow photochemistry, Atmos. Chem. Phys., 8, 171-208, doi:10.5194/acp-8-171-2008, 2008.

Frey, M. M., Hutterli, M. A., Chen, G., Sjostedt, S. J., Burkhar t, J. F., Friel, D. K., and Bales, R. C.: Contrasting atmospheric boundar y layer chemistr y of methylhydroperox- ide $(\mathrm{CH} 3$ $\mathrm{OOH})$ and hydrogen peroxide $\left(\mathrm{H}_{2} \mathrm{O}_{2}\right)$ above polar snow, Atmos. Chem. Phys., 9, 3261-3276, 2009, http://www.atmos-chem-phys.net/9/3261/2009/.

Galbavy, E. S., Anastasio, C., Lefer, B., and Hall, S.: Light penetration in the snowpack at Summit, Greenland. Part 2 Nitrate photolysis, Atmos. Environ., 41, 5091-5100, doi:10.1016/j.atmosenv.2006.01.066, 2007.
Grannas, A. M., Shepson, P. B., and Filley, T. R.: Photochemistry and nature of organic matter in Arctic and Antarctic snow, Global Biogeochem. Cy., 18, GB1006, doi:10.1029/2003GB002133, 2004.

Grannas, A. M., Jones, A. E., Dibb, J., Ammann, M., Anastasio, C., Beine, H. J., Bergin, M., Bottenheim, J., Boxe, C. S., Carver, G., Chen, G., Crawford, J. H., Dominé, F., Frey, M. M., Guzmán, M. I., Heard, D. E., Helmig, D., Hoffmann, M. R., Honrath, R. E., Huey, L. G., Hutterli, M., Jacobi, H. W., Klán, P., Lefer, B., McConnell, J., Plane, J., Sander, R., Savarino, J., Shepson, P. B., Simpson, W. R., Sodeau, J. R., von Glasow, R., Weller, R., Wolff, E. W., and Zhu, T.: An overview of snow photochemistry: evidence, mechanisms and impacts, Atmos. Chem. Phys., 7, 43294373, doi:10.5194/acp-7-4329-2007, 2007.

Helmig, D., Boulter, J., David, D., Birks, J. W., Cullen, N. J., Steffen, K., Johnson, B. J., and Oltmans, S. J.: Ozone and meteorological boundary-layer conditions at Summit, Greenland, during June 3-12 June 2000, Atmos. Environ., 36, 2595-2608, doi:10.1016/S1352-2310(02)00129-2, 2002.

Helmig, D., Ganzeveld, L., Butler, T., and Oltmans, S. J.: The role of ozone atmosphere-snow gas exchange on polar, boundary-layer tropospheric ozone - a review and sensitivity analysis, Atmos. Chem. Phys., 7, 15-30, doi:10.5194/acp-7-15-2007, 2007.

Helmig, D., Johnson, B., Oltmans, S. J., Neff, W., Eisele, F., and Davis, D. D.: Elevated ozone in the boundary layer at South Pole, Atmos. Environ., 42, 2788-2803, doi:10.1016/j.atmosenv.2006.12.032, 2008.

Honrath, R. E., Peterson, M. C., Guo, S., Dibb, J. E., Shepson, P. B., and Campbell, B.: Evidence of $\mathrm{NO}_{\mathrm{x}}$ production Within or Upon Ice Particles in the Greenland Snowpack, Geophys. Res. Lett., 26, 695-698, doi:10.1029/1999GL900077, 1999.

Honrath, R. E., Peterson, M. C., Dziobak, M. P., Dibb, J. E., Arsenault, M. A., and Green, S. A.: Release of $\mathrm{NO}_{\mathrm{x}}$ from Sunlightirradiated Midlatitude Snow, Geophys. Res. Lett., 27, 22372240, doi:10.1029/1999GL011286, 2000.

Honrath, R. E., Lu, Y., Peterson, M. C., Dibb, J. E., Arsenault, M. A., Cullen, N. J., and Steffen, K.: Vertical fluxes of $\mathrm{NO}_{\mathrm{x}}$, $\mathrm{HONO}$, and $\mathrm{HNO}_{3}$ above the snowpack at Summit, Greenland, Atmos. Environ., 36, 2629-2640, doi:10.1016/S13522310(02)00132-2, 2002.

Hutterli, M. A., Rothlisberger, R., and Bales, R. C.: Atmosphere-to-snow-to-firn transfer studies of $\mathrm{HCHO}$ at Summit, Greenland, Geophys. Res. Lett., 26, 1691-1694, doi:10.1029/1999GL900327, 1999.

Hutterli, M. A., McConnell, J. R., Stewart, R. W., Jacobi, H.-W., and Bales, R. C.: Impact of temperature-driven cycling of hydrogen peroxide $\left(\mathrm{H}_{2} \mathrm{O}_{2}\right)$ between air and snow on the planetary boundary layer, J. Geophys. Res., 106, 15395-15404, doi:10.1029/2001JD900102, 2001.

Hutterli, M. A., McConnell, J. R., Bales, R. C., and Stewart, R. W.: Sensitivity of hydrogen peroxide $\left(\mathrm{H}_{2} \mathrm{O}_{2}\right)$ and formaldehyde $(\mathrm{HCHO})$ preservation in snow to changing environmental conditions: Implications for ice core records, J. Geophys. Res., 108, 4023, doi:10.1029/2002JD002528, 2003.

Jacobi, H.-W., Frey, M. M., Hutterli, M. A., Bales, R. C., Schrems, O., Cullen, N. J., Steffen, K., and Koehler, C.: Measurements of hydrogen peroxide and formaldehyde exchange between the atmosphere and surface snow at Summit, Greenland, Atmos. Environ., 36, 2619-2628, doi:10.1016/S1352-2310(02)00106-1, 
2002.

Jacobi, H.-W., Bales, R. C., Honrath, R. E., Peterson, M. C., Dibb, J. E., Swanson, A. L., and Albert, M. R.: Reactive trace gases measured in the interstitial air of surface snow at Summit, Greenland, Atmos. Environ., 38, 1687-1697, doi:10.1016/j.atmosenv.2004.01.004, 2004.

Jones, A. E., Weller, R., Anderson, P. S., Jacobi, H.-W., Wolff, E. W., Schrems, O., and Miller, H.: Measurements of $\mathrm{NO}_{\mathrm{x}}$ emissions from the Antarctic snowpack, Geophys. Res. Lett., 28, 1499-1502, doi:10.1029/2000GL011956, 2001.

Liao, J., Huey, L. G., Tanner, D. J., Brough, N., Brooks, S., Dibb, J. E., Stutz, J., Thomas, J. L., Lefer, B., Haman, C., and Gorham, K.: Observations of hydroxyl and peroxy radicals and the impact of BrO at Summit, Greenland in 2007 and 2008, Atmos. Chem. Phys., 11, 8577-8591, doi:10.5194/acp-11-8577-2011, 2011.

Kuo, M. H., Moussa, S. G., and McNeill, V. F.: Modeling interfacial liquid layers on environmental ices, Atmos. Chem. Phys., 11, 9971-9982, 10.5194/acp-11-9971-2011, 2011.

Liao, W. and Tan, D.: 1-D Air-snowpack modeling of atmospheric nitrous acid at South Pole during ANTCI 2003, Atmos. Chem. Phys., 8, 7087-7099, doi:10.5194/acp-8-7087-2008, 2008.

Lind, J. A. and Kok, G. L.: Correction to "Henry's law determinations for aqueous solutions of hydrogen peroxide, methylhydroperoxide, and peroxyacetic acid" by John A. Lind and Gregory L. Kok, J. Geophys. Res., 99D, 21119, doi:10.1029/94JD01155, 1994.

Michalowski, B. A., Francisco, J. S., Li, S.-M., Barrie, L. A., Bottenheim, J. W., and Shepson, P. B.: A computer model study of multiphase chemistry in the Arctic boundary layer during polar sunrise, J. Geophys. Res., 105, 15131-15145, doi:10.1029/2000JD900004, 2000.

Morin, S., Savarino, J., Bekki, S., Gong, S., and Bottenheim, J. W.: Signature of Arctic surface ozone depletion events in the isotope anomaly $(\Delta 17 \mathrm{O})$ of atmospheric nitrate, Atmos. Chem. Phys., 7, 1451-1469, doi:10.5194/acp-7-1451-2007, 2007.

Morin, S., Savarino, J., Frey, M. M., Yan, N., Bekki, S., Bottenheim, J. W., and Martins, J. M. F.: Tracing the Origin and Fate of $\mathrm{NO}_{\mathrm{X}}$ in the Arctic Atmosphere Using Stable Isotopes in Nitrate, Science, 322, 730-732, doi:10.1126/science.1161910, 2008.

Peterson, M. C. and Honrath, R. E.: Observations of rapid photochemical destruction of ozone in snowpack interstitial air, Geophys. Res. Lett., 28, 511-514, doi:10.1029/2000GL012129, 2001.

Rosenberg, R.: Why Is Ice Slippery?, Phys. Today, 58, 50-55, doi:10.1063/1.2169444, 2005.

Shetter, R. E. and Müller, M.: Photolysis frequency measurements using actinic flux spectroradiometry during the PEM-Tropics mission: Instrumentation description and some results, J. Geophys. Res., 104, 5647-5661, doi:10.1029/98JD01381, 1999.

Simpson, W. R., von Glasow, R., Riedel, K., Anderson, P., Ariya, P., Bottenheim, J., Burrows, J., Carpenter, L. J., Frieß, U., Goodsite, M. E., Heard, D., Hutterli, M., Jacobi, H.-W., Kaleschke, L., Neff, B., Plane, J., Platt, U., Richter, A., Roscoe, H., Sander, R., Shepson, P., Sodeau, J., Steffen, A., Wagner, T., and Wolff, E.: Halogens and their role in polar boundary-layer ozone depletion, Atmos. Chem. Phys., 7, 4375-4418, doi:10.5194/acp-74375-2007, 2007.
Sjostedt, S. J., Huey, L. G., Tanner, D. J., Peischl, J., Chen, G., Dibb, J. E., Lefer, B., Hutterli, M. A., Beyersdorf, A. J., Blake, N. J., Blake, D. R., Sueper, D., Ryerson, T., Burkhart, J., and Stohl, A.: Observations of hydroxyl and the sum of peroxy radicals at Summit, Greenland during summer 2003, Atmos. Environ., 41, 5122-5137, doi:10.1016/j.atmosenv.2006.06.065, 2007.

Stohl, A., Forster, C., Frank, A., Seibert, P., and Wotawa, G.: Technical note: The Lagrangian particle dispersion model FLEXPART version 6.2, Atmos. Chem. Phys., 5, 2461-2474, doi:10.5194/acp-5-2461-2005, 2005.

Stutz, J., Thomas, J. L., Hurlock, S. C., Schneider, M., von Glasow, R., Piot, M., Gorham, K., Burkhart, J. F., Ziemba, L., Dibb, J. E., and Lefer, B. L.: Longpath DOAS observations of surface BrO at Summit, Greenland, Atmos. Chem. Phys., 11, 9899-9910, doi:10.5194/acp-11-9899-2011, 2011.

Sumner, A. L. and Shepson, P. B.: Snowpack production of formaldehyde and its effect on the Arctic troposphere, Nature, 398, 230-233, doi:10.1038/18423, 1999.

Sumner, A. L., Shepson, P. B., Grannas, A. M., Bottenheim, J. W., Anlauf, K. G., Worthy, D., Schroeder, W. H., Steffen, A., Domine, F., Perrier, S., and Houdier, S.: Atmospheric chemistry of formaldehyde in the Arctic troposphere at Polar Sunrise, and the influence of the snowpack, Atmos. Environ., 36, 2553-2562, doi:10.1016/S1352-2310(02)00105-X, 2002.

Thomas, J. L., Stutz, J., Lefer, B., Huey, L. G., Toyota, K., Dibb, J. E., and von Glasow, R.: Modeling chemistry in and above snow at Summit, Greenland - Part 1: Model description and results, Atmos. Chem. Phys., 11, 4899-4914, doi:10.5194/acp-11-48992011, 2011.

Villena, G., Wiesen, P., Cantrell, C. A., Flocke, F., Fried, A., Hall, S. R., Hornbrook, R. S., Knapp, D., Kosciuch, E., Mauldin, R. L., I., McGrath, J. A., Montzka, D., Richter, D., Ullmann, K., Walega, J., Weibring, P., Weinheimer, A., Staebler, R. M., Liao, J., Huey, L. G., and Kleffmann, J.: Nitrous acid (HONO) during polar spring in Barrow, Alaska: A net source of $\mathrm{OH}$ radicals?, J. Geophys. Res., 116, D00R07, doi:10.1029/2011JD016643, 2011.

Yang, J., Honrath, R., Peterson, M., Dibb, J., Sumner, A., Shepson, P., Frey, M., Jacobi, H.-W., Swanson, A., and Blake, N.: Impacts of snowpack emissions on deduced levels of $\mathrm{OH}$ and peroxy radicals at Summit, Greenland, Atmos. Environ., 36, 2523-2534, doi:10.1016/S1352-2310(02)00128-0, 2002.

Zhou, X., Beine, H. J., Honrath, R. E., Fuentes, J. D., Simpson, W., Shepson, P. B., and Bottenheim, J. W.: Snowpack Photochemical production of HONO: A Major Source of $\mathrm{OH}$ in the Arctic Boundary Layer in Springtime, J. Geophys. Res., 28, 4087-4090, doi:10.1029/2001GL013531, 2001. 